\title{
Fine-particle pH for Beijing winter haze as inferred from different thermodynamic equilibrium models
}

\author{
Shaojie Song ${ }^{1, *}$, Meng Gao ${ }^{1, *}$, Weiqi Xu ${ }^{2}$, Jingyuan Shao ${ }^{3,4}$, Guoliang Shi ${ }^{5}$, Shuxiao Wang ${ }^{6}$, Yuxuan Wang ${ }^{7,8}$, \\ Yele Sun $^{2,9}$, and Michael B. McElroy ${ }^{1,10}$ \\ ${ }^{1}$ School of Engineering and Applied Sciences, Harvard University, Cambridge, Massachusetts 02138, USA \\ ${ }^{2}$ State Key Laboratory of Atmospheric Boundary Physics and Atmospheric Chemistry, Institute of Atmospheric Physics, \\ Chinese Academy of Sciences, Beijing 100029, China \\ ${ }^{3}$ Laboratory for Climate and Ocean-Atmosphere Studies, Department of Atmospheric and Oceanic Sciences, \\ School of Physics, Peking University, Beijing 100871, China \\ ${ }^{4}$ Department of Atmospheric Sciences, University of Washington, Seattle, Washington 98195, USA \\ ${ }^{5}$ State Environmental Protection Key Laboratory of Urban Ambient Air Particulate Matter Pollution Prevention and Control, \\ College of Environmental Science and Engineering, Nankai University, Tianjin 300071, China \\ ${ }^{6}$ State Key Joint Laboratory of Environmental Simulation and Pollution Control, School of Environment, \\ Tsinghua University, Beijing 100084, China \\ ${ }^{7}$ Department of Earth and Atmospheric Sciences, University of Houston, Houston, Texas 77004, USA \\ ${ }^{8}$ Department of Earth System Science, Tsinghua University, Beijing 100084, China \\ ${ }^{9}$ University of Chinese Academy of Sciences, Beijing 100049, China \\ ${ }^{10}$ Department of Earth and Planetary Sciences, Harvard University, Cambridge, Massachusetts 02138, USA \\ *These authors contributed equally to this work.
}

Correspondence: Shaojie Song (songs@ seas.harvard.edu), Michael B. McElroy (mbm@seas.harvard.edu) and Yele Sun (sunyele@mail.iap.ac.cn)

Received: 3 January 2018 - Discussion started: 30 January 2018

Revised: 12 April 2018 - Accepted: 7 May 2018 - Published: 28 May 2018

\begin{abstract}
H}$ is an important property of aerosol particles but is difficult to measure directly. Several studies have estimated the $\mathrm{pH}$ values for fine particles in northern China winter haze using thermodynamic models (i.e., E-AIM and ISORROPIA) and ambient measurements. The reported $\mathrm{pH}$ values differ widely, ranging from close to 0 (highly acidic) to as high as 7 (neutral). In order to understand the reason for this discrepancy, we calculated $\mathrm{pH}$ values using these models with different assumptions with regard to model inputs and particle phase states. We find that the large discrepancy is due primarily to differences in the model assumptions adopted in previous studies. Calculations using only aerosol-phase composition as inputs (i.e., reverse mode) are sensitive to the measurement errors of ionic species, and inferred $\mathrm{pH}$ values exhibit a bimodal distribution, with peaks between -2 and 2 and between 7 and 10, depending on whether anions or cations are in excess. Calculations using total (gas plus
\end{abstract}

aerosol phase) measurements as inputs (i.e., forward mode) are affected much less by these measurement errors. In future studies, the reverse mode should be avoided whereas the forward mode should be used. Forward-mode calculations in this and previous studies collectively indicate a moderately acidic condition ( $\mathrm{pH}$ from about 4 to about 5 ) for fine particles in northern China winter haze, indicating further that ammonia plays an important role in determining this property. The assumed particle phase state, either stable (solid plus liquid) or metastable (only liquid), does not significantly impact $\mathrm{pH}$ predictions. The unrealistic $\mathrm{pH}$ values of about 7 in a few previous studies (using the standard ISORROPIA model and stable state assumption) resulted from coding errors in the model, which have been identified and fixed in this study. 


\section{Introduction}

Aerosols in the atmosphere are reported to be associated with respiratory and cardiovascular diseases and affect climate and ecosystems via aerosol-radiation-cloud interactions (Ramanathan et al., 2001; Lim et al., 2012; Ma et al., 2016). Liquid water is a ubiquitous component of aerosols (Nguyen et al., 2016). The hydrogen ion activity expressed on a logarithmic scale, $\mathrm{pH}$, is an essential property describing the acidity of aqueous aerosols and has been suggested to influence particle formation, toxicity, and nutrient delivery. $\mathrm{pH}$ plays a role in the formation of sulfate and secondary organic aerosols (Jang et al., 2002; L. Xu et al., 2015; Cheng et al., 2016), and it also changes the gas-particle partitioning of semi-volatile species (Keene et al., 2004; Guo et al., 2016; Weber et al., 2016). It affects the solubility of trace metals and thus aerosol toxicity (Ghio et al., 2012; Fang et al., 2017). Low pH may enhance iron mobility in dust and impact ocean productivity (Meskhidze et al., 2003).

In spite of its significance, ambient particle $\mathrm{pH}$ is still poorly constrained. The direct filter sampling approach is challenged by the nature of hydrogen ions in that its concentration in a solution does not scale in proportion to the level of dilution, and it is also subject to sampling errors (Hennigan et al., 2015). A few studies have determined the $\mathrm{pH}$ of laboratory-generated particles using colorimetry/spectrometry and Raman microspectroscopy ( $\mathrm{Li}$ and Jang, 2012; Rindelaub et al., 2016; Craig et al., 2017), but such techniques have not been applied to ambient particles, partly due to their much more complex chemical and physical properties. Therefore, an indirect (or proxy) method - thermodynamic equilibrium modeling - has been widely used to estimate particle $\mathrm{pH}$ for many regions of the world (Yao et al., 2007; Zhang et al., 2007; Bougiatioti et al., 2016; Guo et al., 2017a; Murphy et al., 2017; Parworth et al., 2017). A number of thermodynamic models have been developed, subject to the principle of minimizing the Gibbs energy of the multi-phase aerosol system, leading to a computationally intensive optimization problem. Thus these models usually incorporate a variety of simplifications and assumptions in their calculations (Fountoukis and Nenes, 2007).

Over the past few years, several studies have estimated values of fine-particle $\mathrm{pH}$ during northern China winter haze events using the E-AIM (Friese and Ebel, 2010) and ISORROPIA (Fountoukis and Nenes, 2007) thermodynamic equilibrium models, as summarized in Table 1 . The inferred $\mathrm{pH}$ values varied significantly, ranging from close to 0 (highly acidic) to about 7 (neutral). The primary goal of this study is to critically examine the reason for such a large discrepancy. In order to address this problem, we calculate particle $\mathrm{pH}$ using the ISORROPIA and E-AIM models under different assumptions (e.g., open vs. closed systems and stable vs. metastable states). The measured data on gas and particle compositions and meteorological parameters collected in Beijing winter serve as model inputs. We have identified and fixed important coding errors in ISORROPIA which are caused in $\mathrm{pH}$ calculations when a closed system and the stable state are assumed (details are given in the Supplement, Sect. S1). We compare $\mathrm{pH}$ values obtained from these different thermodynamic calculations in Sect. 3.1 and 3.2, as well as in Sect. 3.3, with results from previous winter haze studies. The assumptions and limitations of thermodynamic models are discussed in Sect. 3.4.

\section{Methods}

\subsection{Field measurements}

During winter 2014 (from 17 November to 12 December), measurements of air pollutants were conducted at an urban site in Beijing (Institute of Atmospheric Physics, Chinese Academy of Sciences, $39^{\circ} 58^{\prime} \mathrm{N} 116^{\circ} 22^{\prime} \mathrm{E}$; $49 \mathrm{~m}$ a.s.l.). The $\mathrm{PM}_{2.5}$ and $\mathrm{PM}_{1}$ chemical compositions and several semi-volatile gases were measured with a high time resolution, as described below. The ambient temperature and relative humidity $(\mathrm{RH})$ were recorded by a Rotronic HC2-S3 probe. Concentrations of carbon monoxide were also measured (Model 48i, Thermo Fisher Scientific Inc., USA).

The concentrations of six water-soluble inorganic ions (i.e., $\mathrm{SO}_{4}^{2-}, \mathrm{NO}_{3}^{-}, \mathrm{Cl}^{-}, \mathrm{NH}_{4}^{+}, \mathrm{Na}^{+}$, and $\mathrm{K}^{+}$) in $\mathrm{PM}_{2.5}$ and three semi-volatile gases (i.e., $\mathrm{NH}_{3}, \mathrm{HNO}_{3}$, and $\mathrm{HCl}$ ) were measured with a time resolution of 30 min using the Gas and Aerosol Collector Ion Chromatography (GAC-IC) system. The instrument was modified based on the Steam Jet Aerosol Collector (Khlystov et al., 1995) in order that it better applies to the heavily polluted conditions in China. Ambient air was drawn in at a flow rate of $16.7 \mathrm{~L} \mathrm{~min}^{-1}$ through a $\mathrm{PM}_{2.5}$ cyclone inlet. Trace gases were absorbed in a wet annular denuder and then the water-soluble ions in the aerosols were extracted with an improved aerosol collector. The samples of aqueous solution were quantified by two ion chromatography analyzers. Details on the GAC-IC performance (including the detection limits for each species) were described in a previous publication (Dong et al., 2012). The measurement uncertainties arise from several inaccuracies such as internal calibration, pressure and flow control, and collection efficiencies. The intercomparison experiments with filter sampling and other online methods (e.g., Monitor for AeRosols and Gases in Ambient Air, MARGA; Metrohm, Switzerland) reveal that the overall relative uncertainties of the GAC-IC system remain within $\pm 20 \%$ for major species (Dong et al., 2012; Young et al., 2016).

An Aerodyne high-resolution time-of-flight aerosol mass spectrometer (referred to as the AMS) was used to measure size-resolved non-refractory submicron aerosol (NR$\mathrm{PM}_{1}$ ) species (DeCarlo et al., 2006). The detailed operations and calibrations of the AMS have been described elsewhere (W. Q. Xu et al., 2015; Sun et al., 2016). Briefly, aerosol particles were drawn into the sampling chamber at a flow 
Table 1. Previously reported cation-to-anion equivalent ratios and particle $\mathrm{pH}$ values during winter haze periods in northern China.

\begin{tabular}{|c|c|c|c|c|c|c|c|c|}
\hline City & Year & $\begin{array}{l}\text { Time } \\
\text { resolution }\end{array}$ & Size & Model & Equivalent ratio & $\mathrm{pH}$ & Note & Reference \\
\hline \multicolumn{9}{|c|}{ Forward (closed) } \\
\hline Beijing & 2015 & $1 \mathrm{~h}$ & $\mathrm{PM}_{1}$ & $\begin{array}{l}\text { ISORROPIA } \\
\text { Stable }^{\mathrm{c}}\end{array}$ & $1.09 \pm 0.11$ & $7.6 \pm 0.0$ & $\begin{array}{l}\mathrm{PM}_{2.5}=114 \pm 44 \mu \mathrm{g} \mathrm{m}^{-3} \\
\mathrm{RH}=56 \pm 14 \%\end{array}$ & Wang et al. (2016) \\
\hline Beijing $^{a}$ & $\begin{array}{l}2014 / \\
2015\end{array}$ & $12 \mathrm{~h}$ & $\mathrm{PM}_{2.5}$ & $\begin{array}{l}\text { ISORROPIA } \\
\text { Stable }\end{array}$ & 1.16 & $7.6 \pm 0.1$ & $\begin{array}{l}\mathrm{PM}_{2.5}>75 \mu \mathrm{g} \mathrm{m}^{-3} \\
\mathrm{RH}=62 \pm 12 \%\end{array}$ & He et al. (2018) \\
\hline Xi'an & 2012 & $1 \mathrm{~h}$ & $\mathrm{PM}_{2.5}$ & $\begin{array}{l}\text { ISORROPIA } \\
\text { Stable }^{\mathrm{c}}\end{array}$ & $1.06 \pm 0.06$ & $7.0 \pm 1.3$ & $\begin{array}{l}\mathrm{PM}_{2.5}=250 \pm 120 \mu \mathrm{g} \mathrm{m}^{-3} \\
\mathrm{RH}=68 \pm 14 \%\end{array}$ & Wang et al. (2016) \\
\hline Beijing & 2013 & $2 \mathrm{~h}$ & $\mathrm{PM}_{2.5}$ & $\begin{array}{l}\text { ISORROPIA } \\
\text { Metastable }\end{array}$ & 1.08 & 5.4 & Average of January & Cheng et al. (2016) \\
\hline Beijing & $\begin{array}{l}2015 / \\
2016\end{array}$ & $1 \mathrm{~h}$ & $\mathrm{PM}_{2.5}$ & $\begin{array}{l}\text { ISORROPIA } \\
\text { Metastable }\end{array}$ & 0.99 & $4.2 \pm 0.5$ & $\mathrm{RH}=68 \pm 16 \%$ & M. Liu et al. (2017) \\
\hline Beijing ${ }^{a}$ & $\begin{array}{l}2014 / \\
2015\end{array}$ & $12 \mathrm{~h}$ & $\mathrm{PM}_{2.5}$ & $\begin{array}{l}\text { ISORROPIA } \\
\text { Metastable }\end{array}$ & 1.16 & $4.4 \pm 0.6$ & $\begin{array}{l}\mathrm{PM}_{2.5}>75 \mu \mathrm{g} \mathrm{m}^{-3} \\
\mathrm{RH}=62 \pm 12 \%\end{array}$ & He et al. (2018) \\
\hline Beijing & 2014 & 1 day & $\mathrm{PM}_{2.5}$ & $\begin{array}{l}\text { ISORROPIA } \\
\text { Metastable }\end{array}$ & 1.2 & 4.1 & $\mathrm{PM}_{2.5}>150 \mu \mathrm{g} \mathrm{m}^{-3}$ & Tan et al. (2018) \\
\hline Tianjin & $\begin{array}{l}2014 / \\
2015\end{array}$ & $1 \mathrm{~h}$ & $\mathrm{PM}_{2.5}$ & $\begin{array}{l}\text { ISORROPIA } \\
\text { Metastable }\end{array}$ & 1.13 & $4.9 \pm 0.4$ & $\mathrm{RH}=72 \pm 10 \%$ & Shi et al. (2017) \\
\hline \multicolumn{9}{|c|}{ Reverse (open) } \\
\hline Beijing & 2013 & $2 \mathrm{~h}$ & $\mathrm{PM}_{2.5}$ & $\begin{array}{l}\text { ISORROPIA } \\
\text { Metastable }\end{array}$ & 1.08 & 6.2 & Average of January ${ }^{\mathrm{e}}$ & Cheng et al. (2016) \\
\hline Beijing & 2013 & 1 day & $\mathrm{PM}_{2.1}$ & E-AIM & 1.16 & 1.1 & $\begin{array}{l}\mathrm{PM}_{2.5}>150 \mu \mathrm{g} \mathrm{m}^{-3} \\
\mathrm{RH}>60 \%\end{array}$ & Tian et al. (2018) \\
\hline Beijing $^{b}$ & $\begin{array}{l}2005 / \\
2006\end{array}$ & 7 day & $\mathrm{PM}_{2.5}$ & E-AIM ${ }^{\mathrm{d}}$ & 1.09 & $1.2 \pm 1.1$ & $\mathrm{RH}=63 \pm 15 \%$ & He et al. (2012) \\
\hline Jinan & $\begin{array}{l}2006 / \\
2007\end{array}$ & 1 day & $\mathrm{PM}_{1}$ & E-AIM ${ }^{\mathrm{d}}$ & $\begin{array}{r}\text { Not } \\
\text { available }\end{array}$ & -1 & $\mathrm{PM}_{1.8}=193 \mu \mathrm{g} \mathrm{m}^{-3}$ & Cheng et al. (2011) \\
\hline
\end{tabular}

rate of $10 \mathrm{~L} \mathrm{~min}^{-1}$, of which $\sim 0.1 \mathrm{~L} \mathrm{~min}^{-1}$ was isokinetically sampled into the AMS after being dried with a silica gel dryer. Concentrations were obtained for organics, sulfate, nitrate, ammonium, and chloride. The AMS was calibrated for ionization efficiency using pure $\mathrm{NH}_{4} \mathrm{NO}_{3}$ particles following standard protocols (Jayne et al., 2000). A constant collection efficiency of 0.5 was chosen because (1) particles were dried before being analyzed, (2) the mass fraction of $\mathrm{NH}_{4} \mathrm{NO}_{3}$ was smaller than 0.4 , and (3) the particle acidity was not high enough to affect collection efficiency substantially (Sun et al., 2016). The default relative ionization efficiencies, except for ammonium that was determined from pure $\mathrm{NH}_{4} \mathrm{NO}_{3}$, were applied to all of the species for mass quantifications. The overall uncertainties for each species were estimated following Bahreini et al. (2009), with details provided in Sect. S2.

\section{2 $\mathrm{pH}$ prediction by thermodynamic models}

In this study, $\mathrm{pH}$ is defined in Eq. (1) as the negative logarithm with base 10 of the hydrogen ion activity on a molality basis, which is recommended by IUPAC (www.goldbook. iupac.org/html/P/P04524.html, last access: 22 May 2018) and is also consistent with previous studies (Guo et al., 2016; Battaglia et al., 2017; Pye et al., 2018).

$\mathrm{pH}=-\log _{10}\left(\gamma_{\mathrm{H}^{+}} m_{\mathrm{H}^{+}}\right)=-\log _{10} m_{\mathrm{H}^{+}}-\log _{10} \gamma_{\mathrm{H}^{+}}$,

where $m_{\mathrm{H}^{+}}$and $\gamma_{\mathrm{H}^{+}}$indicate the molality ( $\mathrm{mol} \mathrm{kg}^{-1}$ water) and the molality-based activity coefficient (a factor accounting for deviations from ideal behavior) of hydrogen ions, respectively. Here, particle $\mathrm{pH}$ is predicted using the latest E-AIM (version IV; www.aim.env.uea.ac.uk, last access: 22 May 2018) and ISORROPIA (version II; www.isorropia. eas.gatech.edu, last access: 22 May 2018) thermodynamic equilibrium models. E-AIM is usually considered to be a benchmark model (Zaveri et al., 2008; Seinfeld and Pandis, 2016), while ISORROPIA employs a number of simplifications to make it computationally efficient for application in large-scale atmospheric models (Fountoukis and Nenes, 2007; Pye et al., 2009). E-AIM uses the Pitzer, Simonson, and Clegg equations to calculate activity coefficients for water and ions (Pitzer and Simonson, 1986; Clegg et al., 1992; Wexler and Clegg, 2002). With ISORROPIA, $\gamma_{\mathrm{H}^{+}}$and $\gamma_{\mathrm{OH}^{-}}$ are assumed to be equal to unity, whereas the activity coefficients for the other ionic pairs (e.g., $\mathrm{H}^{+}-\mathrm{Cl}^{-}$) are calculated (Fountoukis and Nenes, 2007). For both models, the 
equilibrium state is calculated at a given temperature and RH. E-AIM solves for the equilibrium of an $\mathrm{NH}_{4}^{+}-\mathrm{H}^{+}-\mathrm{Na}^{+}-$ $\mathrm{SO}_{4}^{2-}-\mathrm{NO}_{3}^{-}-\mathrm{Cl}^{-}-\mathrm{H}_{2} \mathrm{O}$ inorganic aerosol system and its precursor gases $\left(\mathrm{HNO}_{3}, \mathrm{NH}_{3}\right.$, and $\left.\mathrm{HCl}\right)$, and can also include certain organic compounds. E-AIM assumes that the inorganic ions and organic solutes do not influence each other in the aqueous solution, when estimating their activity coefficients (Clegg et al., 2001). ISORROPIA only treats inorganic aerosols but includes more crustal species (i.e., $\mathrm{Ca}$, $\mathrm{K}$, and $\mathrm{Mg}$ ) as compared to E-AIM. The two models can solve for either forward (or closed, in which the total (gas plus aerosol) concentration of each species is fixed) or reverse (or open, in which the concentration of each species in the aerosol phase is fixed) conditions. The model outputs include concentrations for each species in the solid, liquid, and gas phases (Fountoukis and Nenes, 2007).

It is well known that atmospheric aerosol particles can exist in two states of thermodynamic equilibrium, stable and metastable, depending on their chemical composition and RH history (Rood et al., 1989). Particles in the stable state may be solid, solid plus liquid, or liquid as ambient $\mathrm{RH}$ increases (liquid phase appears when ambient $\mathrm{RH}$ reaches the deliquescence $\mathrm{RH}$ ). If the ambient $\mathrm{RH}$ over a completely liquid aerosol decreases below the deliquescence RH, the aerosol may not crystalize immediately but may constitute a supersaturated aqueous solution (i.e., in the metastable state). The ambient RH varies widely over the North China Plain (NCP) in winter. Synoptic weather patterns are dominated by the Siberian high-pressure system (Jia et al., 2015), under which the northerly winds bring dry and clean air into this region, with ambient $\mathrm{RH}$ often dropping to as low as about $20 \%$ (when aerosol particles are most likely solid). When the northerly winds slacken, often occurring during the NCP winter haze events, the atmospheric conditions are characterized by stagnant inversion, weak southerly winds, and rapid accumulation of both air pollutants and water vapor, and the ambient RH often reaches 80-90\% (when aerosol particles are most likely liquid) (Zheng et al., 2015; Gao et al., 2016; Sun et al., 2016; Wang et al., 2016; Tie et al., 2017; Yin et al., 2017). So far, there has been no observational evidence to suggest whether Beijing winter haze fine particles are in a metastable or stable state. It is also unlikely that particle phase states can be figured out using theoretical calculations because of the very large variability of ambient RH and the difficulty in estimating the efflorescence $\mathrm{RH}$ for multicomponent salts (Seinfeld and Pandis, 2016). Thus, a practical approach is to predict $\mathrm{pH}$ for both stable and metastable states, which can provide an estimate of its uncertainty due to the phase state assumption. In this study, $\mathrm{pH}$ values are calculated in both stable and metastable states using ISORROPIA, whereas E-AIM (version IV) can only address the stable state condition.

We have identified and fixed coding errors in the standard ISORROPIA model, which may significantly affect for- (a) Standard ISORROPIA

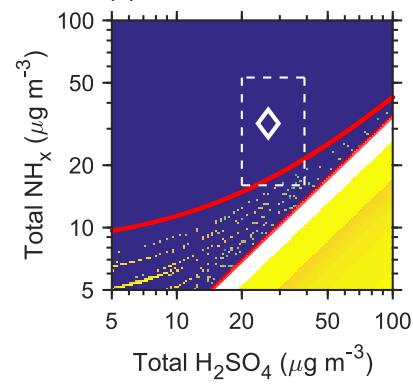

(b) Revised ISORROPIA

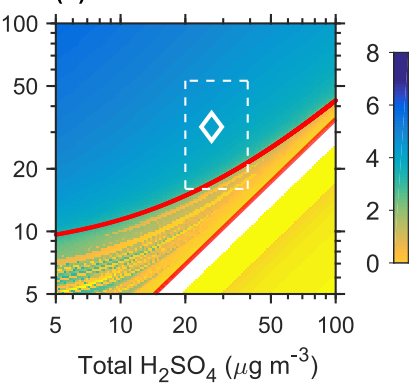

Figure 1. Sensitivity of particle $\mathrm{pH}$ to the total (gas + aerosol) $\mathrm{NH}_{x}$ and $\mathrm{H}_{2} \mathrm{SO}_{4}$ concentrations predicted by the standard (a) and revised (b) ISORROPIA model. Model calculations are conducted in the forward mode with the stable state assumption. The red curves indicate the $\mathrm{NH}_{x}$-rich (above the curve) and $\mathrm{NH}_{x}$-poor (below the curve) regions. The red straight lines are used to distinguish the different sub-regimes in the ISORROPIA solution domain (G1 above the line, and $\mathrm{I} 3$ and $\mathrm{J} 3$ below the line; details are given in Sect. S1). The input data (total $\mathrm{Na}=0 \mu \mathrm{g} \mathrm{m}^{-3}$, total $\mathrm{HNO}_{3}=26 \mu \mathrm{g} \mathrm{m}^{-3}$, total $\mathrm{HCl}=1.7 \mu \mathrm{g} \mathrm{m}^{-3}, \mathrm{RH}=56 \%$, and $T=274.1 \mathrm{~K}$ ) of an $\mathrm{NH}_{3}-\mathrm{Na}-$ $\mathrm{H}_{2} \mathrm{SO}_{4}-\mathrm{HNO}_{3}-\mathrm{HCl}-\mathrm{H}_{2} \mathrm{O}$ aerosol system reflect the average $\mathrm{PM}_{1}$ measurements for Beijing winter haze pollution episodes reported in Wang et al. (2016). The white boxes define the observed concentration ranges for the Beijing winter haze pollution episodes, and diamonds represent the average Beijing haze conditions (total $\mathrm{NH}_{x}=32 \mu \mathrm{g} \mathrm{m}^{-3}$, total $\mathrm{H}_{2} \mathrm{SO}_{4}=26 \mu \mathrm{g} \mathrm{m}^{-3}$ ) reported in Wang et al. (2016). The noises in $\mathrm{pH}$ between the two red lines are due very likely to the instability of the numerical solver currently used in the ISORROPIA model (more information can be found at http: //wiki.seas.harvard.edu/geos-chem/index.php/ISORROPIA_II, last access: 22 May 2018).

ward stable-mode calculations of $\mathrm{pH}$. In this study, the ISORROPIA model with these errors fixed is referred to as the revised ISORROPIA model. Details concerning the revision of ISORROPIA are provided in Sect. S1. Briefly, in several subregimes of the solution domain, the standard ISORROPIA model fails to consider the partitioning of $\mathrm{NH}_{3}$ between the gas and aqueous phases, and therefore the predicted particle $\mathrm{pH}$ is very often around 7 (neutral). Importantly, we find that Beijing winter haze conditions (ammonia-rich) happen to belong to the sub-regimes where coding errors exist. For example, as shown in Fig. 1, the standard ISORROPIA model predicts a nearly constant $\mathrm{pH}$ of 7.6 for most cases when $\frac{\text { total }\left[\mathrm{NH}_{x}\right]}{17}>\frac{\text { total }\left[\mathrm{H}_{2} \mathrm{SO}_{4}\right]}{49}$, where total $\left[\mathrm{NH}_{x}\right]$ and $\left[\mathrm{H}_{2} \mathrm{SO}_{4}\right]$ are the concentrations (gas plus aerosol phase) of the corresponding species. The revised ISORROPIA model predicts a $\mathrm{pH}$ lower than 7 (acidic), which varies as a function of $\left[\mathrm{NH}_{x}\right]$ and $\left[\mathrm{H}_{2} \mathrm{SO}_{4}\right]$. Interestingly, these coding errors have little effect on the predicted gas-phase $\mathrm{NH}_{3}$ concentrations (Wang et al., 2016; Guo et al., 2017b), and thus cannot be identified by simply comparing the measured and predicted $\mathrm{NH}_{3}$ phase partitioning (Sect. S1). A few previous studies have been affected by these ISORROPIA coding errors (Wang et al., 2016; He et al., 2018). 


\subsection{Ion balance and equivalent ratios}

The ion balance and equivalent ratios are calculated using the charge-equivalent measured ion concentrations and Eqs. (2)(5):

$$
\begin{aligned}
& {[\text { cations }]=\frac{\left[\mathrm{NH}_{4}^{+}\right]}{18}+\frac{\left[\mathrm{Na}^{+}\right]}{23}+\frac{\left[\mathrm{K}^{+}\right]}{39}+\frac{\left[\mathrm{Ca}^{2+}\right]}{20}+\frac{\left[\mathrm{Mg}^{2+}\right]}{12}} \\
& {[\text { anions }]=\frac{\left[\mathrm{SO}_{4}^{2-}\right]}{48}+\frac{\left[\mathrm{NO}_{3}^{-}\right]}{62}+\frac{\left[\mathrm{Cl}^{-}\right]}{35.5}} \\
& \text { ion balance }=[\text { cations }]-[\text { anions }] \\
& \text { equivalent ratio }=[\text { cations }] /[\text { anions }],
\end{aligned}
$$

where $\left[\mathrm{NH}_{4}^{+}\right],\left[\mathrm{Na}^{+}\right],\left[\mathrm{K}^{+}\right],\left[\mathrm{Ca}^{2+}\right],\left[\mathrm{Mg}^{2+}\right],\left[\mathrm{SO}_{4}^{2-}\right]$, $\left[\mathrm{NO}_{3}^{-}\right]$, and $\left[\mathrm{Cl}^{-}\right]$are the mass concentrations $\left(\mu \mathrm{g} \mathrm{m}^{-3}\right)$ of these ions in the atmosphere; [cations] and [anions] denote the sum of charge-equivalent total molar concentrations $\left(\mu \mathrm{mol} \mathrm{m}{ }^{-3}\right)$ of cations and anions, respectively. Although they are straightforward to calculate, a few recent studies (Hennigan et al., 2015; Guo et al., 2016; Murphy et al., 2017) have demonstrated that the ion balance and equivalent ratio calculated from ambient particle measurements should not be used to predict the acidity of particles, especially under ammonia-rich conditions, for several reasons summarized as follows. (1) This would require all ions other than $\mathrm{H}^{+}$and $\mathrm{OH}^{-}$to be measured with both very high accuracy and precision, conditions unlikely to be achieved in practice. For example, the filter sampling of semi-volatile species $\left(\mathrm{NH}_{4}^{+}\right.$, $\mathrm{NO}_{3}^{-}$, and $\mathrm{Cl}^{-}$) is subject to both positive and negative biases (Pathak et al., 2004; Wei et al., 2015). Organic acid salts which may contribute significantly to charge balance are usually ignored. In ammonia-rich environments, $\mathrm{H}^{+}$commonly accounts for only a tiny fraction of the total concentrations of ions, and hence its concentration falls within the range of the accumulated analytical uncertainties for measured ions. (2) The dissociation states of many potentially important ionic species (e.g., $\mathrm{HSO}_{4}^{-}$and organic acids) are not considered. (3) The activity coefficients of ionic species are unknown.

\subsection{Overview of measurements and model calculations}

In the measurement period exhibited here, there were five pollution episodes characterized by high particulate matter (PM) concentrations and RH (Fig. S4). The chemical measurements, along with ambient temperature and $\mathrm{RH}$, are converted to hourly averages and used as inputs to E-AIM and ISORROPIA. This study mainly uses $\mathrm{PM}_{2.5}$ data because water-soluble ions are measured and more chemical species $\left(\mathrm{Na}^{+}\right.$and $\left.\mathrm{K}^{+}\right)$are available. The $\mathrm{pH}$ values of $\mathrm{PM}_{1}$ are also estimated for comparison. $\mathrm{SO}_{4}^{2-}, \mathrm{NO}_{3}^{-}, \mathrm{Cl}^{-}$, and $\mathrm{NH}_{4}^{+}$are identified as the major inorganic ions, and their concentrations are positively correlated with RH. With respect to measurements of semi-volatile gases, the mixing ratios of $\mathrm{NH}_{3}$ (18 $\pm 9 \mathrm{ppb}$, median \pm median absolute deviation) are high, whereas $\mathrm{HNO}_{3}(0.08 \pm 0.04 \mathrm{ppb})$ and $\mathrm{HCl}(0.25 \pm 0.07 \mathrm{ppb})$ are observed to be low, consistent with M. Liu et al. (2017). With Eqs. (6)-(8), we can calculate the total (gas $\mathrm{NH}_{3}$ plus particle $\mathrm{NH}_{4}^{+}$) $\mathrm{NH}_{x}$ concentrations, the $\mathrm{NH}_{x}$ concentrations required for the overall (gas plus particle phases) charge balance, and the excess $\mathrm{NH}_{x}$ concentrations.

Total $\mathrm{NH}_{x}=17 \times\left(\frac{\left[\mathrm{NH}_{4}^{+}\right]}{18}+\frac{\left[\mathrm{NH}_{3}\right]}{22.4}\right)$

Required $\mathrm{NH}_{x}=17 \times\left(\frac{\left[\mathrm{SO}_{4}^{2-}\right]}{48}+\frac{\left[\mathrm{NO}_{3}^{-}\right]}{62}+\frac{\left[\mathrm{Cl}^{-}\right]}{35.5}+\right.$

$\left.\frac{\left[\mathrm{HNO}_{3}\right]}{22.4}+\frac{[\mathrm{HCl}]}{22.4}-\frac{\left[\mathrm{Na}^{+}\right]}{23}-\frac{\left[\mathrm{K}^{+}\right]}{39}-\frac{\left[\mathrm{Ca}^{2+}\right]}{20}-\frac{\left[\mathrm{Mg}^{2+}\right]}{12}\right)$

Excess $\mathrm{NH}_{x}=$ total $\mathrm{NH}_{x}-$ required $\mathrm{NH}_{x}$,

where $\left[\mathrm{NH}_{4}^{+}\right],\left[\mathrm{Na}^{+}\right],\left[\mathrm{K}^{+}\right],\left[\mathrm{Ca}^{2+}\right],\left[\mathrm{Mg}^{2+}\right],\left[\mathrm{SO}_{4}^{2-}\right]$, $\left[\mathrm{NO}_{3}^{-}\right]$, and $\left[\mathrm{Cl}^{-}\right]$are the measured concentrations $\left(\mu \mathrm{g} \mathrm{m}^{-3}\right)$ of these ions, and $\left[\mathrm{HNO}_{3}\right],[\mathrm{HCl}]$, and $\left[\mathrm{NH}_{3}\right]$ are the mixing ratios (ppb) of these gases. If excess $\mathrm{NH}_{x}$ is greater (total $\mathrm{NH}_{x}>$ required $\mathrm{NH}_{x}$ ), the system is considered to be $\mathrm{NH}_{x}$-rich. If excess $\mathrm{NH}_{x}$ is less (total $\mathrm{NH}_{x}<$ required $\mathrm{NH}_{x}$ ), the system is considered to be $\mathrm{NH}_{x}$-poor. The field measurements in this and previous studies (Wang et al., 2016; M. Liu et al., 2017) collectively indicate that the Beijing winter haze fine particles are nearly always in an $\mathrm{NH}_{x}$-rich region, as shown in Fig. 2.

The inputs for the forward-mode calculations include the measured total (gas plus aerosol) concentrations of $\mathrm{NH}_{3}$, $\mathrm{H}_{2} \mathrm{SO}_{4}, \mathrm{HCl}, \mathrm{HNO}_{3}, \mathrm{Na}^{+}$, and $\mathrm{K}^{+}$. For the reverse-mode calculations, the inputs involve the measured aerosol-phase concentrations of $\mathrm{NH}_{4}^{+}, \mathrm{SO}_{4}^{2-}, \mathrm{NO}_{3}^{-}, \mathrm{Cl}^{-}, \mathrm{Na}^{+}$, and $\mathrm{K}^{+}$. Note that for E-AIM, the measured concentrations of $\mathrm{K}^{+}$ are accounted for as equivalent $\mathrm{Na}^{+}$. Note also that gaseous $\mathrm{HCl}$ concentrations are taken to be zero in the forward-mode calculations since a large proportion of $\mathrm{HCl}$ data is unavailable. But this treatment only has a very small effect, owing to the low concentrations of gaseous $\mathrm{HCl}$. Model calculations are limited to hourly samples meeting the following criteria: (1) $\mathrm{SO}_{4}^{2-}, \mathrm{NO}_{3}^{-}, \mathrm{Cl}^{-}, \mathrm{NH}_{4}^{+}$, and $\mathrm{NH}_{3}$ (only for the forward mode) are available, and (2) $\mathrm{RH}>20 \%$. The number of eligible samples for ISORROPIA calculations is about 300 , whereas this number for E-AIM is only about 100 since version IV additionally requires $\mathrm{RH}>60 \%$. Moreover, for the ISORROPIA forward-mode $\mathrm{pH}$ calculations, we adopt a Monte Carlo approach to account for the measurement uncertainties of model inputs, including concentrations of ions and gases (uncertainties described in Sect. 2.1), values of temperature (maximum-minimum range of $2{ }^{\circ} \mathrm{C}$ ), and values of relative humidity (maximum-minimum range of $10 \%$ ). All of these variables are assumed to follow a uniform distribution and their values are selected randomly and calculated 5000x for each hourly sample. 


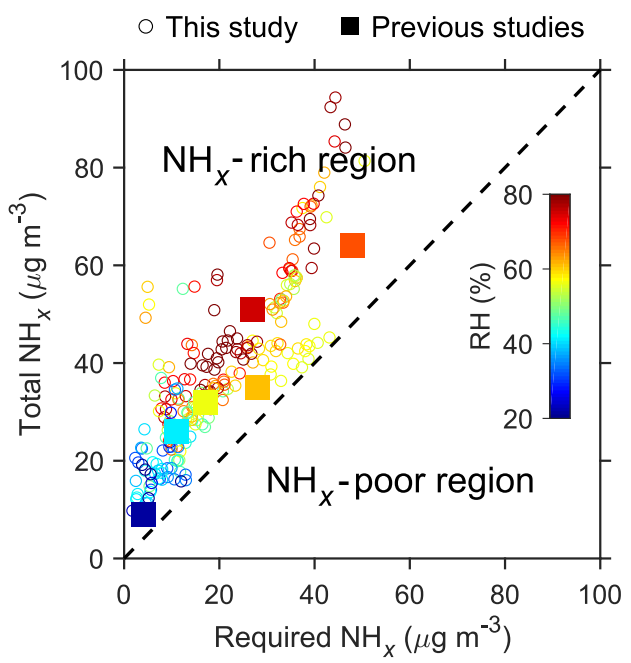

Figure 2. Relationship between required $\mathrm{NH}_{x}$ and total $\mathrm{NH}_{x}$ concentrations under Beijing winter haze conditions. The circles indicate hourly measurements in this study and the filled squares indicate measurement results from previous studies (Wang et al., 2016; M. Liu et al., 2017) for winter in Beijing. The dashed line indicates a 1:1 relationship and defines the $\mathrm{NH}_{x}$-rich region (above) and $\mathrm{NH}_{x}$-poor region (below).

\section{Results and discussion}

\subsection{Reverse-mode calculations}

Figure 3 presents the relationship between ion balance and predicted $\mathrm{pH}$ values for $\mathrm{PM}_{2.5}$ from four model calculations (i.e., ISORROPIA forward metastable, ISORROPIA reverse metastable, E-AIM forward, and E-AIM reverse), as well as a comparison of measured and predicted gas-phase $\mathrm{NH}_{3}$ mixing ratios. As shown in Fig. 3a, a good correlation $(r=0.98$, $n=106)$ is found between the measured cation and anion concentrations, and the average cation-to-anion equivalent ratio $(0.99 \pm 0.18)$ is close to unity (similar to previous northern China winter haze studies; see Table 1). Figure 3b shows that the reverse-mode $\mathrm{pH}$ values (both E-AIM and ISORROPIA) are highly sensitive to whether the ion balance is positive $(n=61)$ or negative $(n=45)$. The samples with negative ion balance (cations $<$ anions) usually project $\mathrm{pH}$ values below 2 (highly acidic), whereas those with positive ion balance (cations $>$ anions) are identified with $\mathrm{pH}$ values above 7.4 (neutral or basic). These features have also been demonstrated by Hennigan et al. (2015) and Murphy et al. (2017) using different observational data sets. Since the inputs to reverse-mode calculations only include aerosol-phase measurements of ions, the predicted $\mathrm{pH}$ values largely depend on the ion balance (Hennigan et al., 2015). On the other hand, the $\mathrm{pH}$ values calculated using the forward mode (both EAIM and ISORROPIA) range from 3.5 to 5.3 and are not as sensitive to the ion balance. This is because the forward- mode calculations account for additional constraints imposed by the partitioning of semi-volatile species. The small difference in $\mathrm{pH}$ values between the forward-mode E-AIM and ISORROPIA calculations is discussed in Sect. 3.2.1. The agreement between the measured and predicted gas-phase concentrations of semi-volatile species usually serves as verification of the accuracy of thermodynamic calculations. Figure $3 \mathrm{c}-\mathrm{d}$ compare measured mixing ratios of $\mathrm{NH}_{3}$ with model outputs. Good agreement is found for the forward mode, but the reverse mode calculations predict either implausibly high $(>1 \mathrm{ppm})$ or implausibly low $(<1 \mathrm{ppb})$ values of $\mathrm{NH}_{3}$, when compared with measurements. The equilibrium partial pressures of $\mathrm{NH}_{3}$ for the reverse mode are computed based on the predicted $\mathrm{pH}$ values with fixed aerosol $\mathrm{NH}_{4}^{+}$concentrations, and hence the extremely large biases of $\mathrm{NH}_{3}$ reflect a significant deviation of $\mathrm{pH}$ with respect to the real values. Similar behavior is found for gas-phase $\mathrm{HNO}_{3}$ and $\mathrm{HCl}$ (Fig. S5).

The above results suggest that the reverse-mode calculations (only using aerosol quantity as model inputs) are strongly affected by the ion balance, and hence the ionic measurement errors are very likely to lead to unreliable estimates of particle pH (Hennigan et al., 2015; Murphy et al., 2017). Furthermore, an equivalent ratio of near unity may not indicate that fine particles of winter haze have a $\mathrm{pH}$ of around 7 or close to 7 (Cheng et al., 2016; Wang et al., 2016; Ma et al., 2017). The forward-mode calculations (using gas plus aerosol quantity as model input) are affected much less by the measurement errors and should be used to predict the $\mathrm{pH}$ for winter haze particles.

\subsection{Forward-mode calculations}

\subsubsection{E-AIM vs. ISORROPIA}

As shown in Fig. 3b, the pH values predicted by the forwardmode E-AIM and ISORROPIA calculations differ slightly. Their $\mathrm{pH}$ difference, $\Delta \mathrm{pH}$ (ISORROPIA - E-AIM), can be expressed in Eq. (9):

$\Delta \mathrm{pH}=\mathrm{pH}_{\mathrm{I}}-\mathrm{pH}_{\mathrm{E}}=-\Delta \log _{10} m_{\mathrm{H}^{+}}+\log _{10} \gamma_{\mathrm{H}^{+}}$,

where $\mathrm{pH}_{\mathrm{I}}$ and $\mathrm{pH}_{\mathrm{E}}$ represent the $\mathrm{pH}$ predicted by ISORROPIA and E-AIM, respectively. $\Delta \mathrm{pH}$ can be considered to consist of two parts: the difference in their estimated $\mathrm{H}^{+}$ concentrations, denoted as $-\Delta \log _{10} m_{\mathrm{H}^{+}}$, and the difference in $\mathrm{H}^{+}$activity coefficients, which is equal to the $\log _{10} \gamma_{\mathrm{H}^{+}}$ estimated by E-AIM (since $\gamma_{\mathrm{H}^{+}}$is assumed to be unity in ISORROPIA). The forward-mode model calculations using our field measurements in Beijing suggest, when $\mathrm{RH}$ varies from 70 to $90 \%$, that $\Delta \mathrm{pH}$ is greater than zero and is negatively correlated with $\mathrm{RH}$ (Fig. $4 \mathrm{a}$ ). $\Delta \mathrm{pH}$ would approach approximately zero, if this relationship were maintained as $\mathrm{RH}$ approaches $100 \%$. Similarly, M. Liu et al. (2017) found that $\mathrm{pH}$ values in ISORROPIA were on average 0.3 units higher than E-AIM under winter haze conditions. Figure $4 \mathrm{~b}$ indi- 

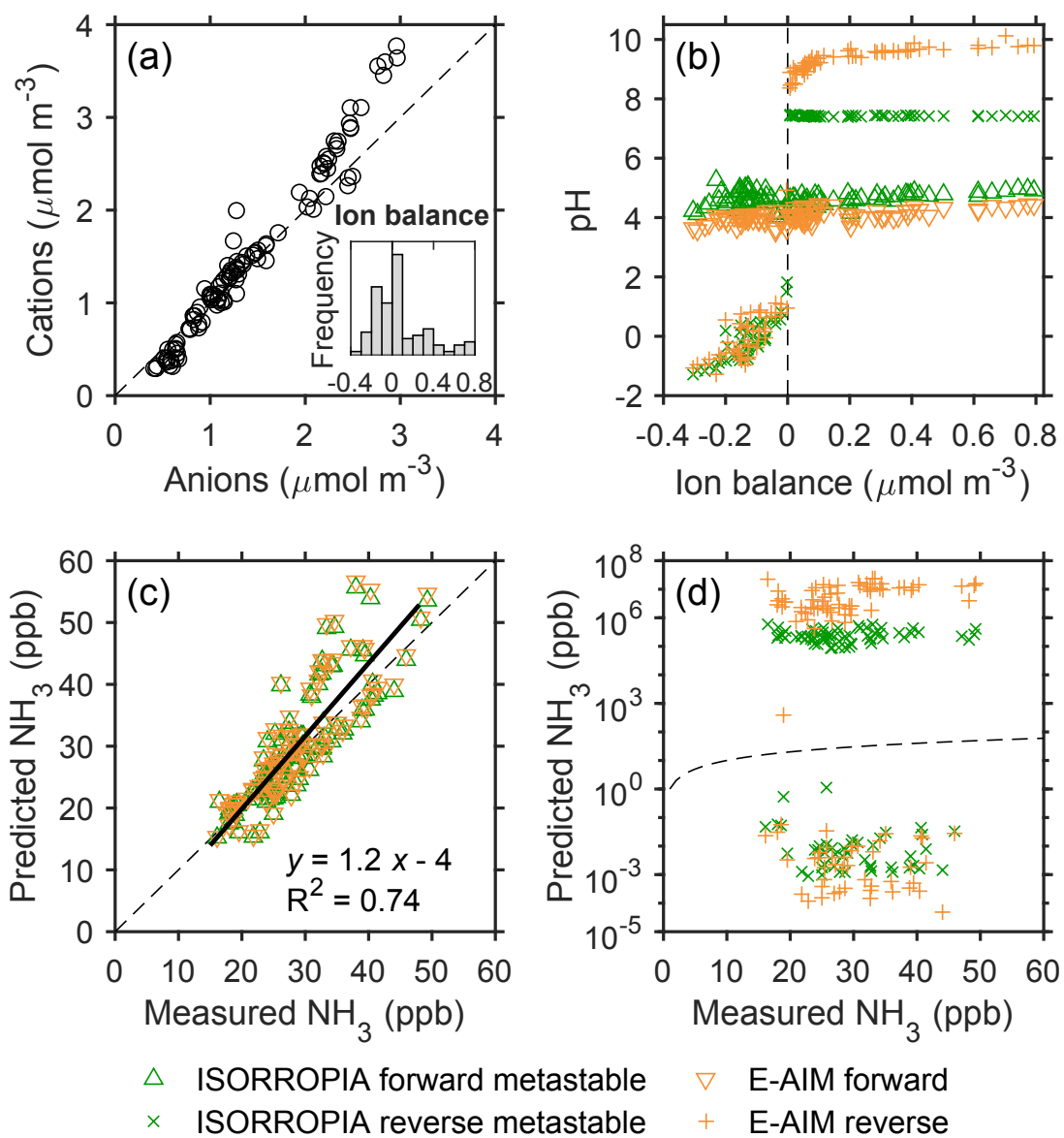

Figure 3. Relationship between ion balance and predicted particle $\mathrm{pH}$ in forward-mode and reverse-mode calculations, and a comparison of measured and predicted gas-phase $\mathrm{NH}_{3}$ mixing ratios. (a) Cation-to-anion equivalent ratios in $\mathrm{PM}_{2.5}$ during the field measurements. The inset figure displays the frequency distribution of ion balance values. The dashed line indicates a $1: 1$ relationship. (b) Predicted pH vs. ion balance. The dashed line indicates ion balance equal to zero. (c-d) Comparisons of predicted and measured gas-phase $\mathrm{NH}_{3}$ mixing ratios. The dashed lines indicate a 1:1 relationship. The solid line in (c) represents the linear correlation between predicted and measured $\mathrm{NH}_{3}$ levels (the ISORROPIA forward metastable and E-AIM forward calculations have essentially the same results). The eligible number of samples $(n=106)$ is limited by the requirement in E-AIM that RH $>60 \%$.

cates that $\Delta \mathrm{pH}$ is related to the differences in both $\mathrm{H}^{+}$concentrations and activity coefficients.

Since E-AIM (version IV) cannot be used when RH is below $60 \%$, we conduct calculations using E-AIM (version II), in order to examine whether this relationship between $\Delta \mathrm{pH}$ and RH still holds at relatively low RH values (Fig. S6 in the Supplement). We find, under typical Beijing winter haze conditions $\left(\mathrm{NH}_{x}\right.$-rich), that $\mathrm{pH}$ predicted by ISORROPIA is systematically higher than E-AIM, and $\Delta \mathrm{pH}$ is negatively related with $\mathrm{RH}$, when $\mathrm{RH}$ varies from 30 to $90 \%$. The exact factors contributing to $\Delta \mathrm{pH}$ remain unclear because these two thermodynamic models differ in many ways (e.g., their methods in calculating the activity coefficients for $\mathrm{H}^{+}$and the other ionic species and in estimating aerosol water contents). Note that $\Delta \mathrm{pH}$ is less than 1 unit for the cases tested in this study, which is much smaller than the $\mathrm{pH}$ discrepancy reported in previous winter haze studies (up to $8 \mathrm{pH}$ units).
Note also that the above analysis is based on the data sets collected in Beijing winter and may not apply to other conditions.

\subsection{2 $S$ curves of semi-volatile species}

The $S$ curves of ammonia, nitric acid, and hydrochloric acid describe the relationship between particle $\mathrm{pH}$ and their equilibrium fractions in the aqueous phase $\left(\varepsilon\left(\mathrm{NH}_{4}^{+}\right)=\left[\mathrm{NH}_{4}^{+}\right] /\left(\left[\mathrm{NH}_{4}^{+}\right]+\left[\mathrm{NH}_{3}\right]\right)\right.$, $\varepsilon\left(\mathrm{NO}_{3}^{-}\right)=\left[\mathrm{NO}_{3}^{-}\right] /\left(\left[\mathrm{NO}_{3}^{-}\right]+\left[\mathrm{HNO}_{3}\right]\right)$, and $\varepsilon\left(\mathrm{Cl}^{-}\right)=$ $\left./\left(\left[\mathrm{Cl}^{-}\right]+[\mathrm{HCl}]\right)\right)$ at a given temperature and aerosol water content (AWC), assuming ideal solutions (water activity and all activity coefficients are equal to unity). The $S$ curves have been shown as useful tools to qualitatively and conceptually estimate particle $\mathrm{pH}$ (Guo et al., 2017a), and are calculated in this study using Henry's law constants and acid-base dissociation constants for each semi-volatile species (details 

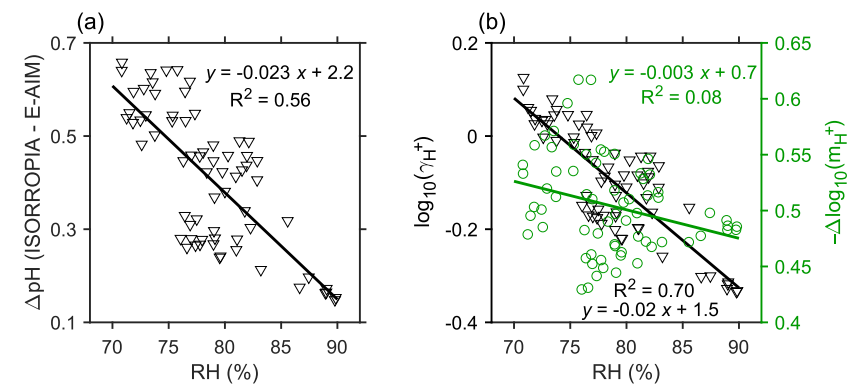

Figure 4. $\mathrm{pH}$ difference between forward-mode E-AIM and ISORROPIA calculations and its relationship with RH. (a) $\Delta \mathrm{pH}$ vs. RH. (b) The relationship between $\mathrm{RH}$ and hydrogen ion activity coefficient from E-AIM (a) and difference in predicted $\mathrm{H}^{+}$concentrations (b). The solid lines indicate linear regressions. For a more appropriate comparison, we choose the samples $(n=68)$ that are in a completely aqueous phase predicted by E-AIM, and $\mathrm{K}^{+}$is accounted for as equivalent $\mathrm{Na}^{+}$in ISORROPIA. The ISORROPIA calculations are carried out assuming a metastable state, but the $\mathrm{pH}$ results are very similar for the stable state when the revised ISORROPIA model is applied.

in Sect. S3). We choose very humid conditions $(\mathrm{RH}>75 \%)$ in the field measurements when particles are most likely in a completely aqueous phase, under which the average temperature and AWC (predicted by ISORROPIA) are $278 \mathrm{~K}$ and $144 \mu \mathrm{g} \mathrm{m}^{-3}$, respectively. As shown in Fig. 5, the calculated $\varepsilon\left(\mathrm{NH}_{4}^{+}\right)$increases with $\mathrm{pH}$, whereas $\varepsilon\left(\mathrm{NO}_{3}^{-}\right)$ and $\varepsilon\left(\mathrm{Cl}^{-}\right)$decrease with $\mathrm{pH}$. The field measurements suggest that about a half of the total ammonia is in the condensed phase $\left(\varepsilon\left(\mathrm{NH}_{4}^{+}\right)=54 \% \pm 12 \%\right)$, and that almost all of the total nitric acid and hydrochloric acid are in the condensed phase $\left(\varepsilon\left(\mathrm{NO}_{3}^{-}\right)=99.6 \% \pm 0.1 \%\right.$ and $\left.\varepsilon\left(\mathrm{Cl}^{-}\right)=98.1 \% \pm 0.7 \%\right)$. Thus, the ammonia $S$ curve and the measured $\varepsilon\left(\mathrm{NH}_{4}^{+}\right)$suggest that the particle $\mathrm{pH}$ should be around 4 and is unlikely to exceed 5.5 when $\varepsilon\left(\mathrm{NH}_{4}^{+}\right)<1 \%$ or below 1.5 when $\varepsilon\left(\mathrm{NH}_{4}^{+}\right)>99 \%$. The $S$ curves for nitric acid and hydrochloric acid and the measured $\varepsilon\left(\mathrm{NO}_{3}^{-}\right)$ and $\varepsilon\left(\mathrm{Cl}^{-}\right)$also suggest that $\mathrm{pH}$ should be greater than 2 , as $\varepsilon\left(\mathrm{NO}_{3}^{-}\right)$and $\varepsilon\left(\mathrm{Cl}^{-}\right)$become close to unity and are consequently insensitive to $\mathrm{pH}$. Note that the assumption of ideal solutions is applied in the above analysis of the $S$ curves. Thermodynamic equilibrium models can calculate the values of activity coefficients (and thus consider the non-ideality of solutions) and are therefore able to provide more quantitative results for particle $\mathrm{pH}$ compared to the $S$ curves. As shown in Fig. 5, the forward-mode ISORROPIA and E-AIM calculations predict similar average $\mathrm{pH}$ values (4.1 and 4.6 respectively), compared to the average number of 3.6 inferred from the $S$ curve of ammonia. Note that calculations using the standard ISORROPIA model with the stable state assumption obtain an unrealistic average $\mathrm{pH}$ value of 7.7 due to its coding errors.
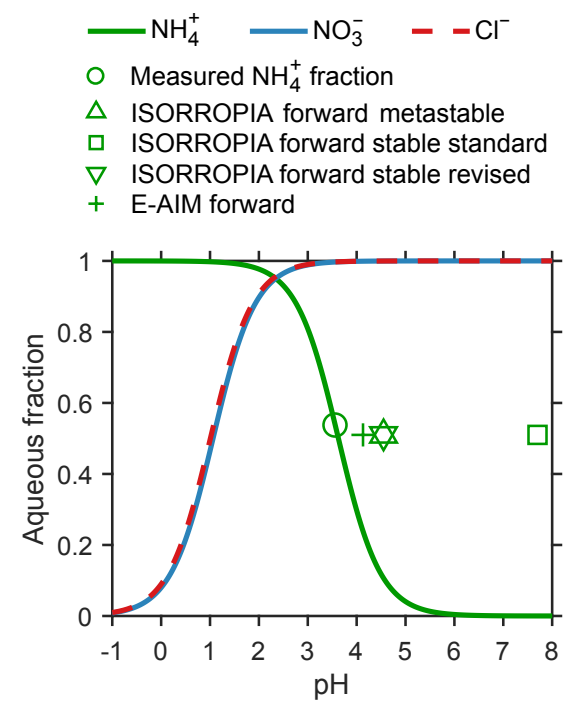

Figure 5. Equilibrium fraction of total ammonia, nitric acid, and hydrochloric acid in the aqueous phase as a function of particle $\mathrm{pH}$. The average temperature $(278 \mathrm{~K})$ and aerosol water content $\left(144 \mu \mathrm{g} \mathrm{m}^{-3}\right)$ during severe haze conditions $(\mathrm{RH}>75 \%)$ are used to calculate these $S$ curves. The circle on top of the ammonia curve indicates the measured average aqueous fraction, which is calculated with the gas-phase $\mathrm{NH}_{3}$ and $\mathrm{PM}_{2.5} \mathrm{NH}_{4}^{+}$concentrations. The corresponding results from different model calculations are also shown as scatter plots: the $x$ axis is the calculated average $\mathrm{pH}$ value and the $y$ axis is the calculated average $\mathrm{NH}_{4}^{+}$aqueous fraction.

\subsubsection{Driving factors for particle $\mathrm{pH}$}

It has been suggested that ambient RH plays an important role in the evolution of winter haze events (Sun et al., 2013; Wang et al., 2014; Tie et al., 2017) and the phase state of aerosols (Y. Liu et al., 2017b). Thus, we present the $\mathrm{pH}$ and AWC values for $\mathrm{PM}_{2.5}$ predicted by the ISORROPIA forward-mode calculations (in both metastable and stable states) as a function of RH (Fig. 6a-b). Note that the revised ISORROPIA model is used for the stable state calculations.

Several previous studies have indicated that the values of AWC predicted by ISORROPIA are in reasonable agreement with those based on measurements of aerosol light scattering coefficients and hygroscopic growth factors (Bian et al., 2014; Guo et al., 2015; Tan et al., 2017; Wu et al., 2018). The predicted AWC increases with RH and is greater for the metastable state (a completely aqueous solution). The absolute difference of AWC between the two states is minor at either high $(>70 \%)$ or low $(<40 \%)$ RH but is large at intermediate RH. Most inorganic species deliquesce at RH below $70 \%$ and, at a higher RH, particles are liquid for both states. At a very low RH, particles are solid in the stable state (thus the AWC is zero and no prediction of $\mathrm{pH}$ is given), but can absorb a small amount of water if they are in the metastable state. 

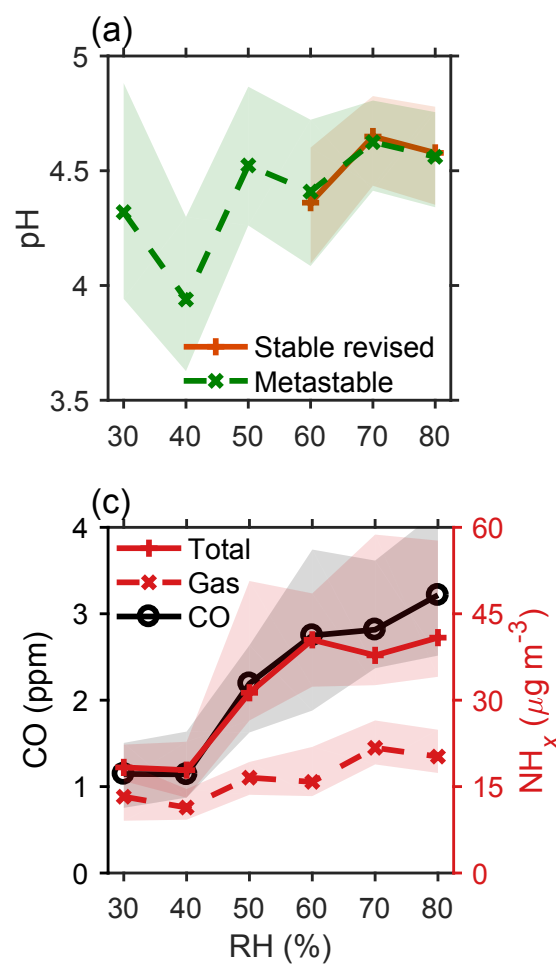

(b)

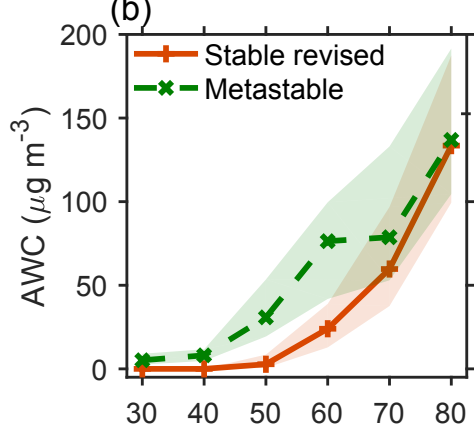

(d)

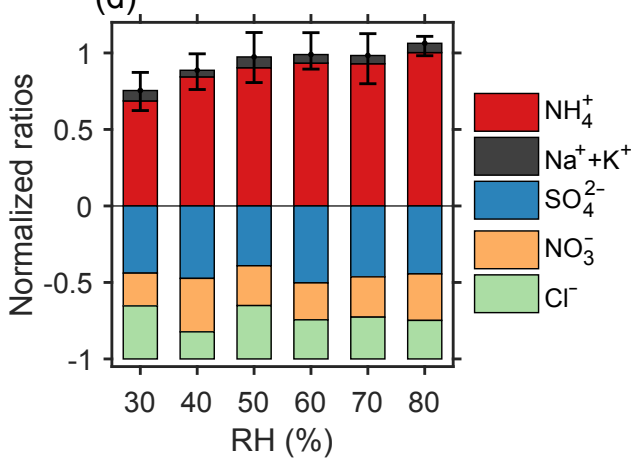

Figure 6. Variations of several chemical and physical parameters as a function of RH. (a-b) $\mathrm{PM}_{2.5} \mathrm{pH}$ and AWC predicted from forwardmode ISORROPIA calculations in both stable and metastable states. (c) Measured concentrations of $\mathrm{CO}$, total (gas plus aerosol) $\mathrm{NH}_{x}$, and gas-phase $\mathrm{NH}_{3}$. For $\mathrm{NH}_{3}, 1 \mu \mathrm{g} \mathrm{m} \mathrm{m}^{-3} \approx 1.3 \mathrm{ppb}$ at standard temperature and pressure. (d) Equivalent ratios of different ions normalized by the levels of total anions. The data are grouped in RH bins (10\% increment). The shaded regions in (a)-(c) and error bars in (d) indicate the 25th and 75th percentiles. The measurement uncertainties of ions and gases are considered in $\mathrm{pH}$ and AWC calculations using a Monte Carlo approach.

As shown in Figs. 6a and $\mathrm{S} 7$, the pH values for these two phase states are very similar (ranging from 4 to 5) and of a moderately acidic nature for a wide range of $\mathrm{RH}$. The results are consistent with the qualitative understanding of particle $\mathrm{pH}$ inferred from the $S$ curves. Thermodynamic model calculations with either stable or metastable state assumptions can provide reasonable estimates of aerosol water $\mathrm{pH}$, at least for the winter haze conditions considered in this study. The $\mathrm{pH}$ values predicted by the AMS $\mathrm{PM}_{1}$ measurements and forward-mode ISORROPIA calculations (Fig. S8) are about 0.2 units lower than those of $\mathrm{PM}_{2.5}$, due partly to a lack of crustal ions $\left(\mathrm{Na}^{+}\right.$and $\left.\mathrm{K}^{+}\right)$for the $\mathrm{AMS} \mathrm{PM}_{1}$ measurements.

By analyzing the sensitivity of $\mathrm{pH}$ to ammonia concentrations, recent studies have emphasized the important role of ammonia in determining winter haze particle $\mathrm{pH}$ (Guo et al., 2017b; M. Liu et al., 2017). It was suggested, under ammonia-rich conditions, that a 10 -fold increase in gasphase $\mathrm{NH}_{3}$ concentrations roughly corresponds to a 1 unit increase in $\mathrm{pH}$ (i.e., a 10-fold decrease in $\mathrm{H}^{+}$activity) (Guo et al., 2017b). This is obvious, since the equilibrium of dissolution and dissociation of ammonia in water can be expressed as $\mathrm{NH}_{3(\mathrm{~g})}+\mathrm{H}_{(\mathrm{aq})}^{+} \leftrightarrow \mathrm{NH}_{4(\mathrm{aq})}^{+}$. These sensitivity tests have also indicated that atmospheric relevant ammonia concentrations are not high enough to achieve a fully neutralized condition ( $\mathrm{pH}$ of around 7) for aerosol particles (Guo et al., 2017b; M. Liu et al., 2017). The sensitivity tests conducted in this study are consistent with these previous studies (Fig. S9).

The ambient RH has a minor effect on the predicted $\mathrm{pH}$ values. An insignificant $(p=0.14)$ increasing trend is calculated from the ISORROPIA metastable analysis in Fig. 6a: $\mathrm{pH}=0.01 \times \mathrm{RH}(\%)+3.9$. A more detailed sensitivity analysis suggests that $\mathrm{pH}$ from ISORROPIA is insensitive to $\mathrm{RH}$ and the variability of $\mathrm{pH}$ is less than 0.3 units within a $\mathrm{RH}$ range of 30-90\% (Fig. S9). On the other hand, the $\mathrm{pH}$ predicted by E-AIM increases by 0.8 units when RH increases from 30 to $90 \%$, reflecting the systematic difference in $\mathrm{pH}$ between ISORROPIA and E-AIM discussed in Sect. 3.2.1.

Our calculations have shown that Beijing winter haze particles are moderately acidic, with $\mathrm{pH}$ values ranging from 4 to 5 for a wide range of RH. As shown in Fig. 6c, our field measurements indicate that the concentrations of $\mathrm{CO}$ and total $\mathrm{NH}_{x}$ (the sum of gas-phase $\mathrm{NH}_{3}$ and aerosol-phase $\mathrm{NH}_{4}^{+}$) exhibit similar increasing trends with ambient $\mathrm{RH}$. $\mathrm{CO}$ is usually considered to be an inactive chemical species during rapid haze formation and its enhancement with increased RH may be taken to reflect the accumulation of pri- 
mary pollutants in the shallower boundary layer (Tie et al., 2017). Thus, the total $\mathrm{NH}_{x}$ is accumulated as a primary pollutant and undergoes a considerable gas-to-particle conversion (Wang et al., 2015; Wei et al., 2015). The $\mathrm{NH}_{3}$ to $\mathrm{NH}_{4}^{+}$ ratio decreases from about 3 at a $\mathrm{RH}$ of $30 \%$ to about 1 at a $\mathrm{RH}$ of $80 \%$. However, relatively high levels of $\mathrm{NH}_{3}$ remain in the gas phase throughout the range of $\mathrm{RH}$ considered here. Note that the measured gas-phase $\mathrm{HNO}_{3}$ and $\mathrm{HCl}$ mixing ratios were very low. Based on the above evidence, we suggest that the amount of total $\mathrm{NH}_{x}$ is rich enough so as to balance most of the $\mathrm{HNO}_{3}, \mathrm{H}_{2} \mathrm{SO}_{4}$, and $\mathrm{HCl}$ formed in gas and particle phases (Fig. 6d). Comparable $\mathrm{NH}_{3}$ levels have been measured at multiple sites over the NCP in winter (Wang et al., 2016; Xu et al., 2016; Zhao et al., 2016; M. Liu et al., 2017), indicating that ammonia-rich conditions are common. Thus, we suggest that ammonia may strongly affect particle $\mathrm{pH}$ over the NCP from clean to hazy conditions (low to high RHs). The sources of ammonia include agriculture, fossil fuel use, and green space, and their contributions vary in different environments (Pan et al., 2016; Sun et al., 2017; Teng et al., 2017; Zhang et al., 2018). We note however that the similar behavior of $\mathrm{CO}$ and total $\mathrm{NH}_{x}$ does not imply necessarily similar emission sources.

\subsection{Summary of existing studies}

In the analysis so far, we have examined the impacts of different thermodynamic models (E-AIM vs. ISORROPIA), model configurations (forward vs. reverse), and phase states (stable vs. metastable) on the estimation of fine-particle $\mathrm{pH}$ using the data sets collected during winter 2014 in Beijing. Here we summarize and compare the existing fine-particle $\mathrm{pH}$ studies of northern China winter haze, highlighting the importance of using an appropriate thermodynamic modeling approach. Figure 7 presents predicted $\mathrm{pH}$ from these studies. Their experimental details are summarized in Table 1.

The average reverse-mode $\mathrm{pH}$ reported by previous studies ranged from -1 to 6.2 (Cheng et al., 2011, 2016; He et al., 2012; Tian et al., 2018). Our calculations show that the reverse-mode $\mathrm{pH}$ has a bimodal distribution, with peaks between -2 and 2 (highly acidic) and between 7 and 10 (basic), and is very sensitive to errors in ionic measurements (Sect. 3.1). In fact, this implies, for an observational study, that the average $\mathrm{pH}$ calculated from many individual samples can be any value between -2 and 10 for E-AIM (between -2 and 8 for ISORROPIA), depending on the number of samples with negative and positive ion balances. The mean $\mathrm{pH}$ values in our calculations are 5.4 and 4.2 for E-AIM and ISORROPIA, respectively, which happen to show a weakly acidic condition.

The forward-mode $\mathrm{pH}$ is affected much less by measurement errors and exhibits thus a narrow unimodal distribution according to our calculations. The average $\mathrm{pH}$ values are 4.6 (95\% confidence interval 4.0 to 5.1 ) and 4.0 (95\% confi- dence interval 3.6 to 4.4 ) for ISORROPIA and E-AIM, respectively. It is essential to note that the revised ISORROPIA when running in the stable state yields an almost identical distribution as compared to ISORROPIA in the metastable state. The studies using the standard ISORROPIA model with the stable state assumption have predicted unrealistic $\mathrm{pH}$ values of around 7 and should be reevaluated (Wang et al., 2016; He et al., 2018). Previous ISORROPIA calculations using the metastable state assumption obtained average $\mathrm{pH}$ values from 4.1 to 5.4 (Cheng et al., 2016; Guo et al., 2017b; M. Liu et al., 2017; Shi et al., 2017; He et al., 2018; Tan et al., 2018), agreeing reasonably with our results (an average $\mathrm{pH}$ value of 4.6). The $\mathrm{Ca}^{2+}$ and $\mathrm{Mg}^{2+}$ concentrations were not measured in this study and a sensitivity test suggests that including these crustal cations in calculations would increase predicted $\mathrm{pH}$ values by about 0.1 units (Fig. S10). Among these studies, the highest $\mathrm{pH}$ value of 5.4 was obtained in Beijing in January 2013 (Cheng et al., 2016) and may be related to two factors: the contribution of organics to AWC was considered, which might increase the $\mathrm{pH}$ values for about 0.1 units, and the $\mathrm{NH}_{3}$ concentrations estimated from an empirical relationship with $\mathrm{NO}_{x}$ might be biased high (He et al., 2014; Pan et al., 2016).

The above comparison suggests that the large discrepancy in $\mathrm{pH}$ values (from about 0 to about 7) reported in previous studies of northern China winter haze may be attributed primarily to differences in the applications of thermodynamic models. We suggest the use of the forward mode rather than the reverse mode in future studies, and the use of the revised ISORROPIA model when the stable state is assumed for the particle phase. The appropriate applications of thermodynamic modeling indicate a moderately acidic condition (pH from about 4 to about 5) for fine particles in northern China winter haze.

\subsection{Assumptions and limitations of thermodynamic modeling}

It is important to acknowledge that most thermodynamic equilibrium models, including E-AIM and ISORROPIA, incorporate a few basic assumptions. First, gas and particle phases are assumed to be equilibrated. This seems reasonable given that we use hourly measurement data and that the equilibration timescale for semi-volatile species between gas and submicron particles is estimated to be 15-30 min (Fountoukis et al., 2009). Second, the aerosol curvature effect on equilibrium partial pressures of semi-volatile species (also known as the Kelvin effect) is ignored. This should have a negligible impact on bulk properties as the effect is only important for particles with sizes smaller than $0.1 \mu \mathrm{m}$, a fraction that does not contribute significantly to the mass of $\mathrm{PM}_{2.5}$ particles (Nenes et al., 1998). Third, aerosols are assumed to be internally mixed and are treated as bulk properties, meaning that all the particles have the same size and chemical composition (Nenes et al., 1998; Box and Box, 2015). Note 

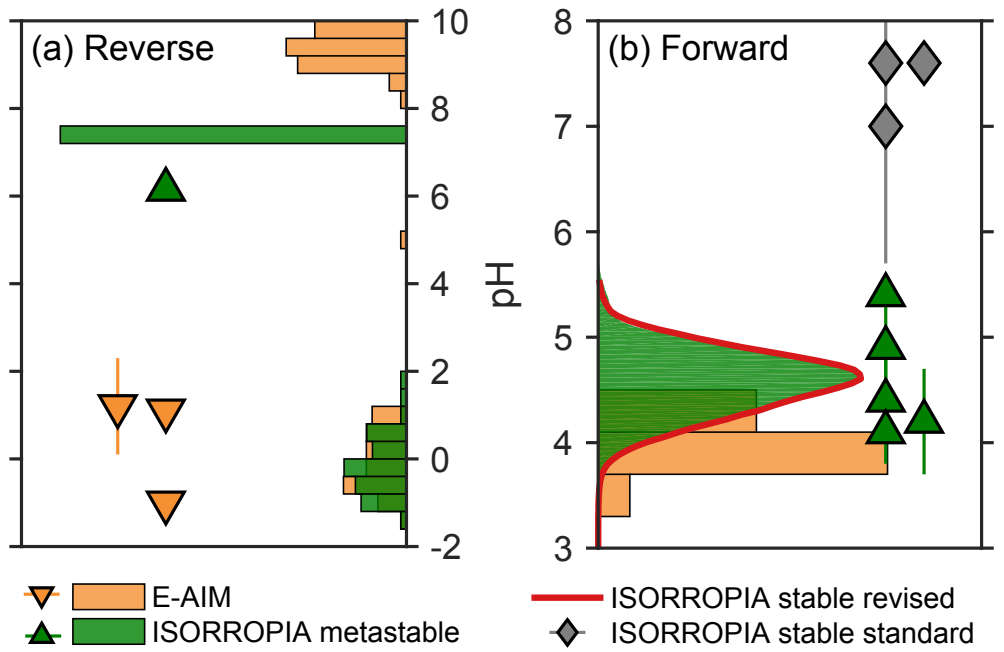

Figure 7. $\mathrm{pH}$ predictions during northern China winter haze events from this and previous studies. Note differences in $\mathrm{pH}$ scales for the reverse-mode (a) and forward-mode (b) calculations. The frequency distributions and symbols reflect results from this and previous studies, respectively. Here we only include our samples during winter haze events (RH > 60\%), with a Monte Carlo approach used in the ISORROPIA forward-mode calculations to better account for the ionic and gas measurement uncertainties.

that only the measured inorganic components are included in the above calculations, whereas organic compounds, which account for about $30-50 \%$ of total fine-particle mass during winter haze events (Huang et al., 2014; Zhang et al., 2015; Tan et al., 2018), are not considered. Organics may affect particle $\mathrm{pH}$ in several ways: (1) by increasing the absorption of aerosol water, (2) by participating in the charge balance and modifying the activity coefficients of inorganic ions in the aqueous phase, and (3) by changing the aerosol-phase state (liquid-liquid phase separation). Next, we will discuss these aspects.

1. The contribution of organics to aerosol water is parameterized, usually based on the hygroscopicity parameter $\kappa_{\text {org }}$ (Guo et al., 2015; Cheng et al., 2016):

$W_{\text {org }}=\mathrm{OM} \frac{\rho_{\mathrm{w}}}{\rho_{\text {org }}} \frac{\kappa_{\text {org }}}{(100 \% / \mathrm{RH}-1)}$,

where $W_{\text {org }}$ is the aerosol water associated with organics, OM is the mass concentration of organics, and $\rho_{\mathrm{w}}$ $\left(1.0 \times 10^{3} \mathrm{~kg} \mathrm{~m}^{-3}\right)$ and $\rho_{\text {org }}\left(1.4 \times 10^{3} \mathrm{~kg} \mathrm{~m}^{-3}\right)$ are the densities of water and organics, respectively. The average $\kappa_{\text {org }}$ of 0.06 was obtained from an earlier cloud condensation nuclei study in Beijing (Gunthe et al., 2011). Black carbon (BC) may also absorb water with an average $\kappa$ of 0.04 from Peng et al. (2017). Using the OM and $\mathrm{BC}$ concentrations measured by the AMS and a $\mathrm{PM}_{2.5} / \mathrm{PM}_{1}$ conversion factor of 1.6 (Zhao et al., 2017), we find that the aerosol water associated with these species is only about $14 \pm 3 \%$ (median \pm median absolute deviation) of that associated with inorganic salts, and thus has a very minor impact on the predicted $\mathrm{pH}$ values of fine particles (Fig. S11). The particle $\mathrm{pH}$ values increase by $0.05 \pm 0.01$, consistent with M. Liu et al. (2017). Even with a $\kappa_{\text {org }}$ of 0.2 (a potential upper limit) (Zhao et al., 2015), the change of particle $\mathrm{pH}$ $(0.13 \pm 0.03)$ is still small.

2. It has been suggested that organic compounds (e.g., amines and organic acid salts) may affect particle $\mathrm{pH}$, especially under weakly acidic conditions (Hennigan et al., 2015). Due to a lack of detailed measurements of these species, a thorough evaluation of their effect is difficult. Here, we conduct a sensitivity test using the E-AIM model including oxalate $\left(\mathrm{C}_{2} \mathrm{O}_{4}^{2-}\right)$, which is the most abundant organic acid salt in $\mathrm{PM}_{2.5}$ in winter in Beijing (Huang et al., 2005; Wang et al., 2017) and is also one of the strongest organic acids (acid dissociation constants $p K_{\mathrm{a} 1}=1.27$ and $\left.p K_{\mathrm{a} 2}=4.27\right)$. Strong positive correlations are measured between oxalate and sulfate, and their ratios are about 1-2\% (Wang et al., 2017). Considering also the relative concentration levels of oxalate and other organic acid salts (Table S8), the oxalate concentration is set at $20 \%$ of sulfate in this test, which may represent the upper limit for the concentration of total organic acids. The $\mathrm{pH}$ values predicted by the forward mode E-AIM only decrease by $0.07 \pm 0.03$ when oxalate is included (Fig. S12), indicating that particle $\mathrm{pH}$ is not strongly affected by organic acids if the system is equilibrated. Note that E-AIM assumes that the organics in the aqueous solution do not affect the activity coefficients of inorganic ions (Clegg et al., 2001). Using the AIOMFAC model (http://web.meteo.mcgill.ca/aiomfac, last access: 22 May 2018), Pye et al. (2018) have recently shown that the interaction of inorganic ions with water-soluble 
organic compounds resulted in a 0.1 unit increase in $\mathrm{pH}$ for aerosols in the southeast United States.

3. As described earlier, during severe winter haze events at very high $\mathrm{RH}$, the aerosol phase state should be liquid. However, we suggest that the particles very likely undergo liquid-liquid phase separation between the inorganic and organic components. This phase separation is believed to depend primarily on the oxygen-to-carbon $(\mathrm{O} / \mathrm{C})$ atomic ratio (a parameter used to roughly describe the oxidation state) of organic aerosols and occurs almost always when the $\mathrm{O} / \mathrm{C}$ ratio $<0.5$ (Guo et al., 2016; Freedman, 2017). The average O/C ratio calculated based on the AMS $\mathrm{PM}_{1}$ measurements and updated calibrations by Canagaratna et al. (2015) is $0.4 \pm 0.1$ (Fig. S13), similar to values reported previously for winter in Beijing (Hu et al., 2016; Sun et al., 2016). The effect of phase separation on $\mathrm{pH}$ values of these two liquid phases remains unclear. It has been suggested in a recent laboratory study that the $\mathrm{pH}$ of the organic-rich fraction under phase separation is about 0.4 units higher than that for a fully mixed aqueous phase (Dallemagne et al., 2016).

The above discussion suggests that the assumptions and limitations implicit in the thermodynamic models may not lead to large biases in prediction of the bulk $\mathrm{pH}$ of fine particles in northern China winter haze, which is supported by the reasonable agreement between the measured and predicted gasparticle partitioning of semi-volatile species such as ammonia.

\section{Conclusions}

This study suggests that the significant discrepancy of fineparticle $\mathrm{pH}$, ranging from about 0 (highly acidic) to about 7 (neutral), calculated in previous studies of northern China winter haze is due primarily to differences in the ways in which the E-AIM and ISORROPIA thermodynamic equilibrium models have been applied. The reverse-mode calculations (only using aerosol-phase composition as input) lead to erroneous results of $\mathrm{pH}$ since they are strongly affected by ionic measurement errors (especially under ammonia-rich conditions), and therefore should be avoided in future winter haze studies. The forward-mode calculations (using the total (gas plus aerosol phase) compositions as inputs) account for additional constraints imposed by the partitioning of semivolatile species and are affected much less by the measurement errors, and therefore, should be used in future studies. The forward-mode calculations in this and previous studies collectively indicate, during northern China winter haze events, that aerosol particles are moderately acidic, with $\mathrm{pH}$ values ranging from about 4 to about 5 . The assumed particle phase state (stable or metastable) does not significantly affect the $\mathrm{pH}$ calculations of ISORROPIA after coding er- rors in its standard model are fixed. A few previous studies, in which the standard ISORROPIA model was used and the stable state was assumed, predicted unrealistic $\mathrm{pH}$ values of around 7 , and should be reevaluated. In agreement with previous studies, we confirm that ammonia plays an important role in determining particle $\mathrm{pH}$ under winter haze conditions in northern China.

Data availability. The Windows stand-alone executable of the ISORROPIA model is available at www.isorropia.eas.gatech.edu (Nenes et al., 2018). The web-based E-AIM model is available at www.aim.env.uea.ac.uk (Clegg et al., 2018). The measurement data on gas and particle compositions and meteorology are available upon request to the authors. The revision for the forward stable state in the source codes of ISORROPIA made in this study is available at http://wiki.seas.harvard.edu/geos-chem/index. php/ISORROPIA_II (Song and Shao, 2018).

\section{The Supplement related to this article is available online at https://doi.org/10.5194/acp-18-7423-2018-supplement.}

Competing interests. The authors declare that they have no conflict of interest.

Acknowledgements. This study was supported by the Harvard Global Institute and the National Natural Science Foundation of China (91744207, 21625701, 41775149). Yuxuan Wang acknowledges support from NSF AGS 1645062. We thank Athanasios Nenes for helpful discussions and for providing the source codes of ISORROPIA, and Becky Alexander, Michael Battaglia Jr., Simon Clegg, Hongyu Guo, Daniel Jacob, Mingxu Liu, Pengfei Liu, Mario Molina, Rachel Silvern, Gehui Wang, Lin Zhang, and Guangjie Zheng for helpful discussions.

Edited by: David Topping

Reviewed by: two anonymous referees

\section{References}

Bahreini, R., Ervens, B., Middlebrook, A. M., Warneke, C., de Gouw, J. A., DeCarlo, P. F., Jimenez, J. L., Brock, C. A., Neuman, J. A., Ryerson, T. B., Stark, H., Atlas, E., Brioude, J., Fried, A., Holloway, J. S., Peischl, J., Richter, D., Walega, J., Weibring, P., Wollny, A. G., and Fehsenfeld, F. C.: Organic aerosol formation in urban and industrial plumes near Houston and Dallas, Texas, J. Geophys. Res.-Atmos., 114, D00F16, https://doi.org/10.1029/2008JD011493, 2009.

Battaglia, M. A., Douglas, S., and Hennigan, C. J.: Effect of the urban heat island on aerosol pH, Environ. Sci. Technol., 51, 1309513103, https://doi.org/10.1021/acs.est.7b02786, 2017. 
Bian, Y. X., Zhao, C. S., Ma, N., Chen, J., and Xu, W. Y.: A study of aerosol liquid water content based on hygroscopicity measurements at high relative humidity in the North China Plain, Atmos. Chem. Phys., 14, 6417-6426, https://doi.org/10.5194/acp14-6417-2014, 2014.

Bougiatioti, A., Nikolaou, P., Stavroulas, I., Kouvarakis, G., Weber, R., Nenes, A., Kanakidou, M., and Mihalopoulos, N.: Particle water and $\mathrm{pH}$ in the eastern Mediterranean: source variability and implications for nutrient availability, Atmos. Chem. Phys., 16, 4579-4591, https://doi.org/10.5194/acp-16-4579-2016, 2016.

Box, M. A. and Box, G. P.: Physics of radiation and climate, Crc Press, Boca Raton, Florida, 2015.

Canagaratna, M. R., Jimenez, J. L., Kroll, J. H., Chen, Q., Kessler, S. H., Massoli, P., Hildebrandt Ruiz, L., Fortner, E., Williams, L. R., Wilson, K. R., Surratt, J. D., Donahue, N. M., Jayne, J. T., and Worsnop, D. R.: Elemental ratio measurements of organic compounds using aerosol mass spectrometry: characterization, improved calibration, and implications, Atmos. Chem. Phys., 15, 253-272, https://doi.org/10.5194/acp-15-253-2015, 2015.

Cheng, S.-H., Yang, L.-X., Zhou, X.-H., Xue, L.-K., Gao, X.-M., Zhou, Y., and Wang, W.-X.: Size-fractionated water-soluble ions, situ $\mathrm{pH}$ and water content in aerosol on hazy days and the influences on visibility impairment in Jinan, China, Atmos. Environ., 45, 4631-4640, https://doi.org/10.1016/j.atmosenv.2011.05.057, 2011

Cheng, Y., Zheng, G., Wei, C., Mu, Q., Zheng, B., Wang, Z., Gao, M., Zhang, Q., He, K., Carmichael, G., Pöschl, U., and Su, H.: Reactive nitrogen chemistry in aerosol water as a source of sulfate during haze events in China, Sci. Adv., 2, e1601530, https://doi.org/10.1126/sciadv.1601530, 2016.

Clegg, S. L., Pitzer, K. S., and Brimblecombe, P.: Thermodynamics of multicomponent, miscible, ionic solutions. Mixtures including unsymmetrical electrolytes, J. Phys. Chem., 96, 9470-9479, https://doi.org/10.1021/j100202a074, 1992.

Clegg, S., Brimblecombe, P., and Wexler, A.: E-AIM model, www. aim.env.uea.ac.uk last access: 22 May 2018.

Clegg, S. L., Seinfeld, J. H., and Brimblecombe, P.: Thermodynamic modelling of aqueous aerosols containing electrolytes and dissolved organic compounds, J. Aerosol. Sci., 32, 713-738, https://doi.org/10.1016/S0021-8502(00)00105-1, 2001.

Craig, R. L., Nandy, L., Axson, J. L., Dutcher, C. S., and Ault, A. P.: Spectroscopic determination of aerosol $\mathrm{pH}$ from acid-base equilibria in inorganic, organic, and mixed systems, J. Phys. Chem. A, 121, 5690-5699, https://doi.org/10.1021/acs.jpca.7b05261, 2017.

Dallemagne, M. A., Huang, X. Y., and Eddingsaas, N. C.: Variation in $\mathrm{pH}$ of model secondary organic aerosol during liquidliquid phase separation, J. Phys. Chem. A, 120, 2868-2876, https://doi.org/10.1021/acs.jpca.6b00275, 2016.

DeCarlo, P. F., Kimmel, J. R., Trimborn, A., Northway, M. J., Jayne, J. T., Aiken, A. C., Gonin, M., Fuhrer, K., Horvath, T., Docherty, K. S., Worsnop, D. R., and Jimenez, J. L.: Field-deployable, high-resolution, time-of-flight aerosol mass spectrometer, Anal. Chem., 78, 8281-8289, https://doi.org/10.1021/ac061249n, 2006.

Dong, H.-B., Zeng, L.-M., Hu, M., Wu, Y.-S., Zhang, Y.-H., Slanina, J., Zheng, M., Wang, Z.-F., and Jansen, R.: Technical Note: The application of an improved gas and aerosol collector for am- bient air pollutants in China, Atmos. Chem. Phys., 12, 1051910533, https://doi.org/10.5194/acp-12-10519-2012, 2012.

Fang, T., Guo, H., Zeng, L., Verma, V., Nenes, A., and Weber, R. J.: Highly acidic ambient particles, soluble metals, and oxidative potential: a link between sulfate and aerosol toxicity, Environ. Sci. Technol., 51, 2611-2620, https://doi.org/10.1021/acs.est.6b06151, 2017.

Fountoukis, C. and Nenes, A.: ISORROPIA II: a computationally efficient thermodynamic equilibrium model for $\mathrm{K}^{+}$ $\mathrm{Ca}^{2+}-\mathrm{Mg}^{2+}-\mathrm{NH}_{4}^{+}-\mathrm{Na}^{+}-\mathrm{SO}_{4}^{2-}-\mathrm{NO}_{3}^{-}-\mathrm{Cl}^{-}-\mathrm{H}_{2} \mathrm{O}$ aerosols, Atmos. Chem. Phys., 7, 4639-4659, https://doi.org/10.5194/acp-74639-2007, 2007.

Fountoukis, C., Nenes, A., Sullivan, A., Weber, R., Van Reken, T., Fischer, M., Matías, E., Moya, M., Farmer, D., and Cohen, R. C.: Thermodynamic characterization of Mexico City aerosol during MILAGRO 2006, Atmos. Chem. Phys., 9, 2141-2156, https://doi.org/10.5194/acp-9-2141-2009, 2009.

Freedman, M. A.: Phase separation in organic aerosol, Chem. Soc. Rev., 46, 7694-7705, https://doi.org/10.1039/C6CS00783J, 2017.

Friese, E. and Ebel, A.: Temperature dependent thermodynamic model of the system $\mathrm{H}^{+}-\mathrm{NH}_{4}^{+}-\mathrm{Na}^{+}-\mathrm{SO}_{4}^{2-}$. $\mathrm{NO}_{3}^{-}-\mathrm{Cl}^{-}-\mathrm{H}_{2} \mathrm{O}$, J. Phys. Chem. A, 114, 11595-11631, https://doi.org/10.1021/jp101041j, 2010.

Gao, M., Carmichael, G. R., Wang, Y., Saide, P. E., Yu, M., Xin, J., Liu, Z., and Wang, Z.: Modeling study of the 2010 regional haze event in the North China Plain, Atmos. Chem. Phys., 16, 1673-1691, https://doi.org/10.5194/acp-16-1673-2016, 2016.

Ghio, A. J., Carraway, M. S., and Madden, M. C.: Composition of air pollution particles and oxidative stress in cells, tissues, and living systems, J. Toxicol. Env. Heal. B, 15, 1-21, https://doi.org/10.1080/10937404.2012.632359, 2012.

Gunthe, S. S., Rose, D., Su, H., Garland, R. M., Achtert, P., Nowak, A., Wiedensohler, A., Kuwata, M., Takegawa, N., Kondo, Y., Hu, M., Shao, M., Zhu, T., Andreae, M. O., and Pöschl, U.: Cloud condensation nuclei $(\mathrm{CCN})$ from fresh and aged air pollution in the megacity region of Beijing, Atmos. Chem. Phys., 11, 1102311039, https://doi.org/10.5194/acp-11-11023-2011, 2011.

Guo, H., Xu, L., Bougiatioti, A., Cerully, K. M., Capps, S. L., Hite Jr., J. R., Carlton, A. G., Lee, S.-H., Bergin, M. H., Ng, N. L., Nenes, A., and Weber, R. J.: Fine-particle water and $\mathrm{pH}$ in the southeastern United States, Atmos. Chem. Phys., 15, 5211-5228, https://doi.org/10.5194/acp-15-5211-2015, 2015.

Guo, H., Sullivan, A. P., Campuzano-Jost, P., Schroder, J. C., LopezHilfiker, F. D., Dibb, J. E., Jimenez, J. L., Thornton, J. A., Brown, S. S., Nenes, A., and Weber, R. J.: Fine particle pH and the partitioning of nitric acid during winter in the northeastern United States, J. Geophys. Res.-Atmos., 121, 10355-10376, https://doi.org/10.1002/2016JD025311, 2016.

Guo, H., Liu, J., Froyd, K. D., Roberts, J. M., Veres, P. R., Hayes, P. L., Jimenez, J. L., Nenes, A., and Weber, R. J.: Fine particle $\mathrm{pH}$ and gas-particle phase partitioning of inorganic species in Pasadena, California, during the 2010 CalNex campaign, Atmos. Chem. Phys., 17, 5703-5719, https://doi.org/10.5194/acp17-5703-2017, 2017a.

Guo, H., Weber, R. J., and Nenes, A.: High levels of ammonia do not raise fine particle $\mathrm{pH}$ sufficiently to yield nitrogen oxide-dominated sulfate production, Sci. Rep., 7, 12109, https://doi.org/10.1038/s41598-017-11704-0, 2017b. 
He, H., Wang, Y., Ma, Q., Ma, J., Chu, B., Ji, D., Tang, G., Liu, C., Zhang, H., and Hao, J.: Mineral dust and NOx promote the conversion of $\mathrm{SO}_{2}$ to sulfate in heavy pollution days, Sci. Rep., 4, 4172, https://doi.org/10.1038/srep04172, 2014.

He, K., Zhao, Q., Ma, Y., Duan, F., Yang, F., Shi, Z., and Chen, G.: Spatial and seasonal variability of $\mathrm{PM}_{2.5}$ acidity at two Chinese megacities: insights into the formation of secondary inorganic aerosols, Atmos. Chem. Phys., 12, 1377-1395, https://doi.org/10.5194/acp-12-1377-2012, 2012.

He, P., Alexander, B., Geng, L., Chi, X., Fan, S., Zhan, H., Kang, H., Zheng, G., Cheng, Y., Su, H., Liu, C., and Xie, Z.: Isotopic constraints on heterogeneous sulfate production in Beijing haze, Atmos. Chem. Phys., 18, 5515-5528, https://doi.org/10.5194/acp18-5515-2018, 2018.

Hennigan, C. J., Izumi, J., Sullivan, A. P., Weber, R. J., and Nenes, A.: A critical evaluation of proxy methods used to estimate the acidity of atmospheric particles, Atmos. Chem. Phys., 15, 27752790, https://doi.org/10.5194/acp-15-2775-2015, 2015.

Hu, W., Hu, M., Hu, W., Jimenez, J. L., Yuan, B., Chen, W., Wang, M., Wu, Y., Chen, C., Wang, Z., Peng, J., Zeng, L., and Shao, M.: Chemical composition, sources, and aging process of submicron aerosols in Beijing: Contrast between summer and winter, J. Geophys. Res.-Atmos., 121, 1955-1977, https://doi.org/10.1002/2015JD024020, 2016.

Huang, R.-J., Zhang, Y., Bozzetti, C., Ho, K.-F., Cao, J.-J., Han, Y., Daellenbach, K. R., Slowik, J. G., Platt, S. M., Canonaco, F., Zotter, P., Wolf, R., Pieber, S. M., Bruns, E. A., Crippa, M., Ciarelli, G., Piazzalunga, A., Schwikowski, M., Abbaszade, G., SchnelleKreis, J., Zimmermann, R., An, Z., Szidat, S., Baltensperger, U., Haddad, I. E., and Prévôt, A. S. H.: High secondary aerosol contribution to particulate pollution during haze events in China, Nature, 514, 218-222, https://doi.org/10.1038/nature13774, 2014.

Huang, X.-F., Hu, M., He, L.-Y., and Tang, X.-Y.: Chemical characterization of water-soluble organic acids in $\mathrm{PM}_{2.5}$ in Beijing, China, Atmos. Environ., 39, 2819-2827, https://doi.org/10.1016/j.atmosenv.2004.08.038, 2005.

Jang, M., Czoschke, N. M., Lee, S., and Kamens, R. M.: Heterogeneous atmospheric aerosol production by acidcatalyzed particle-phase reactions, Science, 298, 814-817, https://doi.org/10.1126/science.1075798, 2002.

Jayne, J. T., Leard, D. C., Zhang, X., Davidovits, P., Smith, K. A., Kolb, C. E., and Worsnop, D. R.: Development of an aerosol mass spectrometer for size and composition analysis of submicron particles, Aerosol Sci. Technol., 33, 49-70, https://doi.org/10.1080/027868200410840, 2000.

Jia, B., Wang, Y., Yao, Y., and Xie, Y.: A new indicator on the impact of large-scale circulation on wintertime particulate matter pollution over China, Atmos. Chem. Phys., 15, 11919-11929, https://doi.org/10.5194/acp-15-11919-2015, 2015.

Keene, W. C., Pszenny, A. A. P., Maben, J. R., Stevenson, E., and Wall, A.: Closure evaluation of size-resolved aerosol $\mathrm{pH}$ in the New England coastal atmosphere during summer, J. Geophys. Res.-Atmos., 109, D23307, https://doi.org/10.1029/2004JD004801, 2004.

Khlystov, A., Wyers, G. P., and Slanina, J.: The steamjet aerosol collector, Atmos. Environ., 29, 2229-2234, https://doi.org/10.1016/1352-2310(95)00180-7, 1995.

Li, J. and Jang, M.: Aerosol acidity measurement using colorimetry coupled with a Reflectance UV-Visible spectrometer, Aerosol Sci. Technol., 46, 833-842, https://doi.org/10.1080/02786826.2012.669873, 2012.

Lim, S. S., Vos, T., Flaxman, A. D., Danaei, G., Shibuya, K., AdairRohani, H., AlMazroa, M. A., Amann, M., Anderson, H. R., Andrews, K. G., Aryee, M., Atkinson, C., Bacchus, L. J., Bahalim, A. N., Balakrishnan, K., Balmes, J., Barker-Collo, S., Baxter A., Bell, M. L., Blore, J. D., Blyth, F., Bonner, C., Borges, G., Bourne, R., Boussinesq, M., Brauer, M., Brooks, P., Bruce, N. G., Brunekreef, B., Bryan-Hancock, C., Bucello, C., Buchbinder, R., Bull, F., Burnett, R. T., Byers, T. E., Calabria, B., Carapetis, J., Carnahan, E., Chafe, Z., Charlson, F., Chen, H., Chen, J. S., Cheng, A. T.-A., Child, J. C., Cohen, A., Colson, K. E., Cowie, B. C., Darby, S., Darling, S., Davis, A., Degenhardt, L., Dentener, F., Des Jarlais, D. C., Devries, K., Dherani, M., Ding, E. L., Dorsey, E. R., et al.: A comparative risk assessment of burden of disease and injury attributable to 67 risk factors and risk factor clusters in 21 regions, 1990-2010: a systematic analysis for the Global Burden of Disease Study 2010, Lancet, 380, 2224-2260, https://doi.org/10.1016/S0140-6736(12)61766-8, 2012.

Liu, M., Song, Y., Zhou, T., Xu, Z., Yan, C., Zheng, M., Wu, Z., $\mathrm{Hu}, \mathrm{M}$., Wu, Y., and Zhu, T.: Fine particle $\mathrm{pH}$ during severe haze episodes in northern China, Geophys. Res. Lett., 44, 5213-5221, https://doi.org/10.1002/2017GL073210, 2017.

Liu, Y., Wu, Z., Wang, Y., Xiao, Y., Gu, F., Zheng, J., Tan, T., Shang, D., Wu, Y., Zeng, L., Hu, M., Bateman, A. P., and Martin, S. T.: Submicrometer particles are in the liquid state during heavy haze episodes in the urban atmosphere of Beijing, China, Environ. Sci. Tech. Let., 4, 427-432, https://doi.org/10.1021/acs.estlett.7b00352, 2017.

Ma, G., Wang, J., Yu, F., Guo, X., Zhang, Y., and Li, C.: Assessing the premature death due to ambient particulate matter in China's urban areas from 2004 to 2013, Front. Env. Sci. Eng., 10, 07, https://doi.org/10.1007/s11783-016-0849-7, 2016.

Ma, Q., Wu, Y., Tao, J., Xia, Y., Liu, X., Zhang, D., Han, Z., Zhang, X., and Zhang, R.: Variations of chemical composition and source apportionment of $\mathrm{PM}_{2.5}$ during winter haze episodes in Beijing, Aerosol Air Qual. Res., 17, 2791-2803, https://doi.org/10.4209/aaqr.2017.10.0366, 2017.

Meskhidze, N., Chameides, W. L., Nenes, A., and Chen, G.: Iron mobilization in mineral dust: Can anthropogenic $\mathrm{SO}_{2}$ emissions affect ocean productivity?, Geophys. Res. Lett., 30, 2085, https://doi.org/10.1029/2003GL018035, 2003.

Murphy, J. G., Gregoire, P. K., Tevlin, A. G., Wentworth, G. R., Ellis, R. A., Markovic, M. Z., and VandenBoer, T. C.: Observational constraints on particle acidity using measurements and modelling of particles and gases, Faraday Discuss., 200, 379395, https://doi.org/10.1039/C7FD00086C, 2017.

Nenes, A., Pandis, S. N., and Pilinis, C.: ISORROPIA: A new thermodynamic equilibrium model for multiphase multicomponent inorganic aerosols, Aquat. Geochem., 4, 123-152, https://doi.org/10.1023/a:1009604003981, 1998.

Nenes, A., Fountoukis, C., Pandis, S., and Pilinis, C.: ISORROPIA II model, www.isorropia.eas.gatech.edu, last access: 22 May 2018.

Nguyen, T. K. V., Zhang, Q., Jimenez, J. L., Pike, M., and Carlton, A. G.: Liquid water: ubiquitous contributor to aerosol mass, Environ. Sci. Tech. Let., 3, 257-263, https://doi.org/10.1021/acs.estlett.6b00167, 2016. 
Pan, Y., Tian, S., Liu, D., Fang, Y., Zhu, X., Zhang, Q., Zheng, B., Michalski, G., and Wang, Y.: Fossil fuel combustion-related emissions dominate atmospheric ammonia sources during severe haze episodes: evidence from ${ }^{15} \mathrm{~N}$-stable isotope in sizeresolved aerosol ammonium, Environ. Sci. Technol., 50, 80498056, https://doi.org/10.1021/acs.est.6b00634, 2016.

Parworth, C. L., Young, D. E., Kim, H., Zhang, X., Cappa, C. D., Collier, S., and Zhang, Q.: Wintertime watersoluble aerosol composition and particle water content in Fresno, California, J. Geophys. Res.-Atmos., 122, 3155-3170, https://doi.org/10.1002/2016JD026173, 2017.

Pathak, R. K., Yao, X., and Chan, C. K.: Sampling artifacts of acidity and ionic species in $\mathrm{PM}_{2.5}$, Environ. Sci. Technol., 38, 254 259, https://doi.org/10.1021/es0342244, 2004.

Peng, J., Hu, M., Guo, S., Du, Z., Shang, D., Zheng, J., Zheng, J., Zeng, L., Shao, M., Wu, Y., Collins, D., and Zhang, R.: Ageing and hygroscopicity variation of black carbon particles in Beijing measured by a quasi-atmospheric aerosol evolution study (QUALITY) chamber, Atmos. Chem. Phys., 17, 10333-10348, https://doi.org/10.5194/acp-17-10333-2017, 2017.

Pitzer, K. S. and Simonson, J. M.: Thermodynamics of multicomponent, miscible, ionic systems: theory and equations, J. Phys. Chem., 90, 3005-3009, https://doi.org/10.1021/j100404a042, 1986.

Pye, H. O. T., Liao, H., Wu, S., Mickley, L. J., Jacob, D. J., Henze, D. K., and Seinfeld, J. H.: Effect of changes in climate and emissions on future sulfate-nitrate-ammonium aerosol levels in the United States, J. Geophys. Res.-Atmos., 114, D01205, https://doi.org/10.1029/2008JD010701, 2009.

Pye, H. O. T., Zuend, A., Fry, J. L., Isaacman-VanWertz, G., Capps, S. L., Appel, K. W., Foroutan, H., Xu, L., Ng, N. L., and Goldstein, A. H.: Coupling of organic and inorganic aerosol systems and the effect on gas-particle partitioning in the southeastern US, Atmos. Chem. Phys., 18, 357-370, https://doi.org/10.5194/acp18-357-2018, 2018.

Ramanathan, V., Crutzen, P. J., Kiehl, J. T., and Rosenfeld, D.: Aerosols, climate, and the hydrological cycle, Science, 294, 2119-2124, https://doi.org/10.1126/science.1064034, 2001.

Rindelaub, J. D., Craig, R. L., Nandy, L., Bondy, A. L., Dutcher, C. S., Shepson, P. B., and Ault, A. P.: Direct measurement of $\mathrm{pH}$ in individual particles via Raman Microspectroscopy and variation in acidity with relative humidity, J. Phys. Chem. A, 120, 911917, https://doi.org/10.1021/acs.jpca.5b12699, 2016.

Rood, M. J., Shaw, M. A., Larson, T. V., and Covert, D. S.: Ubiquitous nature of ambient metastable aerosol, Nature, 337, 537-539, https://doi.org/10.1038/337537a0, 1989.

Seinfeld, J. H. and Pandis, S. N.: Atmospheric chemistry and physics: from air pollution to climate change, 3 Edn., John Wiley \& Sons, Inc., Hoboken, New Jersey, 2016.

Shi, G., Xu, J., Peng, X., Xiao, Z., Chen, K., Tian, Y., Guan, X., Feng, Y., Yu, H., Nenes, A., and Russell, A. G.: pH of aerosols in a polluted atmosphere: source contributions to highly acidic aerosol, Environ. Sci. Technol., 51, 4289-4296, https://doi.org/10.1021/acs.est.6b05736, 2017.

Song, S. and Shao, J.: Bug fixes for ISORROPIA II stable mode, http://wiki.seas.harvard.edu/geos-chem/index.php/ ISORROPIA_II, last access: 23 May 2018.

Sun, K., Tao, L., Miller, D. J., Pan, D., Golston, L. M., Zondlo, M. A., Griffin, R. J., Wallace, H. W., Leong, Y. J., Yang,
M. M., Zhang, Y., Mauzerall, D. L., and Zhu, T.: Vehicle emissions as an important urban ammonia source in the United States and China, Environ. Sci. Technol., 51, 2472-2481, https://doi.org/10.1021/acs.est.6b02805, 2017.

Sun, Y., Wang, Z., Fu, P., Jiang, Q., Yang, T., Li, J., and Ge, X.: The impact of relative humidity on aerosol composition and evolution processes during wintertime in Beijing, China, Atmos. Environ., 77, 927-934, https://doi.org/10.1016/j.atmosenv.2013.06.019, 2013.

Sun, Y., Du, W., Fu, P., Wang, Q., Li, J., Ge, X., Zhang, Q., Zhu, C., Ren, L., Xu, W., Zhao, J., Han, T., Worsnop, D. R., and Wang, Z.: Primary and secondary aerosols in Beijing in winter: sources, variations and processes, Atmos. Chem. Phys., 16, 8309-8329, https://doi.org/10.5194/acp-16-8309-2016, 2016.

Tan, H., Cai, M., Fan, Q., Liu, L., Li, F., Chan, P. W., Deng, X., and Wu, D.: An analysis of aerosol liquid water content and related impact factors in Pearl River Delta, Sci. Total Environ., 579, 1822-1830, https://doi.org/10.1016/j.scitotenv.2016.11.167, 2017.

Tan, T., Hu, M., Li, M., Guo, Q., Wu, Y., Fang, X., Gu, F., Wang, Y., and Wu, Z.: New insight into $\mathrm{PM}_{2.5}$ pollution patterns in Beijing based on one-year measurement of chemical compositions, Sci. Total Environ., 621, 734-743, https://doi.org/10.1016/j.scitotenv.2017.11.208, 2018.

Teng, X., Hu, Q., Zhang, L., Qi, J., Shi, J., Xie, H., Gao, H., and Yao, X.: Identification of major sources of atmospheric $\mathrm{NH}_{3}$ in an urban environment in Northern China during wintertime, Environ. Sci. Technol., 51, 6839-6848, https://doi.org/10.1021/acs.est.7b00328, 2017.

Tian, S., Pan, Y., and Wang, Y.: Ion balance and acidity of size-segregated particles during haze episodes in urban Beijing, Atmos. Res., 201, 159-167, https://doi.org/10.1016/j.atmosres.2017.10.016, 2018.

Tie, X., Huang, R.-J., Cao, J., Zhang, Q., Cheng, Y., Su, H., Chang, D., Pöschl, U., Hoffmann, T., Dusek, U., Li, G., Worsnop, D. R., and O'Dowd, C. D.: Severe pollution in China amplified by atmospheric moisture, Sci. Rep., 7, 15760, https://doi.org/10.1038/s41598-017-15909-1, 2017.

Wang, G., Zhang, R., Gomez, M. E., Yang, L., Levy Zamora, M., Hu, M., Lin, Y., Peng, J., Guo, S., Meng, J., Li, J., Cheng, C., Hu, T., Ren, Y., Wang, Y., Gao, J., Cao, J., An, Z., Zhou, W., Li, G., Wang, J., Tian, P., Marrero-Ortiz, W., Secrest, J., Du, Z., Zheng, J., Shang, D., Zeng, L., Shao, M., Wang, W., Huang, Y., Wang, Y., Zhu, Y., Li, Y., Hu, J., Pan, B., Cai, L., Cheng, Y., Ji, Y., Zhang, F., Rosenfeld, D., Liss, P. S., Duce, R. A., Kolb, C. E., and Molina, M. J.: Persistent sulfate formation from London Fog to Chinese haze, P. Natl. Acad. Sci. USA, 113, 13630-13635, https://doi.org/10.1073/pnas.1616540113, 2016.

Wang, J., Wang, G., Gao, J., Wang, H., Ren, Y., Li, J., Zhou, B., Wu, C., Zhang, L., Wang, S., and Chai, F.: Concentrations and stable carbon isotope compositions of oxalic acid and related SOA in Beijing before, during, and after the 2014 APEC, Atmos. Chem. Phys., 17, 981-992, https://doi.org/10.5194/acp-17981-2017, 2017.

Wang, S., Nan, J., Shi, C., Fu, Q., Gao, S., Wang, D., Cui, H., SaizLopez, A., and Zhou, B.: Atmospheric ammonia and its impacts on regional air quality over the megacity of Shanghai, China, Sci. Rep., 5, 15842, https://doi.org/10.1038/srep15842, 2015. 
Wang, Y., Zhang, Q., Jiang, J., Zhou, W., Wang, B., He, K., Duan, F., Zhang, Q., Philip, S., and Xie, Y.: Enhanced sulfate formation during China's severe winter haze episode in January 2013 missing from current models, J. Geophys. Res.-Atmos., 119, 1042510440, https://doi.org/10.1002/2013JD021426, 2014.

Weber, R. J., Guo, H., Russell, A. G., and Nenes, A.: High aerosol acidity despite declining atmospheric sulfate concentrations over the past 15 years, Nat. Geosci., 9, 282-285, https://doi.org/10.1038/ngeo2665, 2016.

Wei, L., Duan, J., Tan, J., Ma, Y., He, K., Wang, S., Huang, X., and Zhang, Y.: Gas-to-particle conversion of atmospheric ammonia and sampling artifacts of ammonium in spring of Beijing, Sci. China-Earth Sci., 58, 345-355, https://doi.org/10.1007/s11430014-4986-1, 2015.

Wexler, A. S. and Clegg, S. L.: Atmospheric aerosol models for systems including the ions $\mathrm{H}^{+}, \mathrm{NH}_{4}^{+}, \mathrm{Na}^{+}, \mathrm{SO}_{4}^{2-}, \mathrm{NO}_{3}^{-}$, $\mathrm{Cl}^{-}, \mathrm{Br}^{-}$, and $\mathrm{H}_{2} \mathrm{O}$, J. Geophys. Res.-Atmos., 107, 4207, https://doi.org/10.1029/2001JD000451, 2002.

Wu, Z., Wang, Y., Tan, T., Zhu, Y., Li, M., Shang, D., Wang, H., Lu, K., Guo, S., Zeng, L., and Zhang, Y.: Aerosol liquid water driven by anthropogenic inorganic salts: implying its key role in haze formation over the North China Plain, Environ. Sci. Tech. Let., 5, 160-166, https://doi.org/10.1021/acs.estlett.8b00021, 2018.

Xu, L., Guo, H., Boyd, C. M., Klein, M., Bougiatioti, A., Cerully, K. M., Hite, J. R., Isaacman-VanWertz, G., Kreisberg, N. M., Knote, C., Olson, K., Koss, A., Goldstein, A. H., Hering, S. V., de Gouw, J., Baumann, K., Lee, S.-H., Nenes, A., Weber, R. J., and $\mathrm{Ng}$, N. L.: Effects of anthropogenic emissions on aerosol formation from isoprene and monoterpenes in the southeastern United States, P. Natl. Acad. Sci. USA, 112, 37-42, https://doi.org/10.1073/pnas.1417609112, 2015a.

Xu, W., Wu, Q., Liu, X., Tang, A., Dore, A. J., and Heal, M. R.: Characteristics of ammonia, acid gases, and $\mathrm{PM}_{2.5}$ for three typical land-use types in the North China Plain, Environ. Sci. Pollut. R., 23, 1158-1172, https://doi.org/10.1007/s11356-015-5648-3, 2016.

Xu, W. Q., Sun, Y. L., Chen, C., Du, W., Han, T. T., Wang, Q. Q., Fu, P. Q., Wang, Z. F., Zhao, X. J., Zhou, L. B., Ji, D. S., Wang, P. C., and Worsnop, D. R.: Aerosol composition, oxidation properties, and sources in Beijing: results from the 2014 Asia-Pacific Economic Cooperation summit study, Atmos. Chem. Phys., 15, 13681-13698, https://doi.org/10.5194/acp-1513681-2015, 2015b.

Yao, X., Ling, T. Y., Fang, M., and Chan, C. K.: Size dependence of in situ $\mathrm{pH}$ in submicron atmospheric particles in Hong Kong, Atmos. Environ., 41, 382-393, https://doi.org/10.1016/j.atmosenv.2006.07.037, 2007.

Yin, Z., Wang, H., and Chen, H.: Understanding severe winter haze events in the North China Plain in 2014: roles of climate anomalies, Atmos. Chem. Phys., 17, 1641-1651, https://doi.org/10.5194/acp-17-1641-2017, 2017.
Young, L.-H., Li, C.-H., Lin, M.-Y., Hwang, B.-F., Hsu, H.-T., Chen, Y.-C., Jung, C.-R., Chen, K.-C., Cheng, D.-H., Wang, V.S., Chiang, H.-C., and Tsai, P.-J.: Field performance of a semicontinuous monitor for ambient $\mathrm{PM}_{2.5}$ water-soluble inorganic ions and gases at a suburban site, Atmos. Environ., 144, 376388, https://doi.org/10.1016/j.atmosenv.2016.08.062, 2016.

Zaveri, R. A., Easter, R. C., Fast, J. D., and Peters, L. K.: Model for Simulating Aerosol Interactions and Chemistry (MOSAIC), J. Geophys. Res.-Atmos., 113, D13204, https://doi.org/10.1029/2007JD008782, 2008.

Zhang, L., Chen, Y., Zhao, Y., Henze, D. K., Zhu, L., Song, Y., Paulot, F., Liu, X., Pan, Y., Lin, Y., and Huang, B.: Agricultural ammonia emissions in China: reconciling bottom-up and top-down estimates, Atmos. Chem. Phys., 18, 339-355, https://doi.org/10.5194/acp-18-339-2018, 2018.

Zhang, Q., Jimenez, J. L., Worsnop, D. R., and Canagaratna, M.: A case study of urban particle acidity and its influence on secondary organic aerosol, Environ. Sci. Technol., 41, 3213-3219, https://doi.org/10.1021/es061812j, 2007.

Zhang, Q., Duan, F., He, K., Ma, Y., Li, H., Kimoto, T., and Zheng, A.: Organic nitrogen in $\mathrm{PM}_{2.5}$ in Beijing, Front. Env. Sci. Eng., 9, 1004-1014, https://doi.org/10.1007/s11783-015-0799-5, 2015.

Zhao, D. F., Buchholz, A., Kortner, B., Schlag, P., Rubach, F., Kiendler-Scharr, A., Tillmann, R., Wahner, A., Flores, J. M., Rudich, Y., Watne, Å. K., Hallquist, M., Wildt, J., and Mentel, T. F.: Size-dependent hygroscopicity parameter $(\kappa)$ and chemical composition of secondary organic cloud condensation nuclei, Geophys. Res. Lett., 42, 10920-10928, https://doi.org/10.1002/2015GL066497, 2015.

Zhao, M., Wang, S., Tan, J., Hua, Y., Wu, D., and Hao, J.: Variation of urban atmospheric ammonia pollution and its relation with $\mathrm{PM}_{2.5}$ chemical property in winter of Beijing, China, Aerosol Air Qual. Res., 16, 1378-1389, https://doi.org/10.4209/aaqr.2015.12.0699, 2016.

Zhao, P., Chen, Y., and Su, J.: Size-resolved carbonaceous components and water-soluble ions measurements of ambient aerosol in Beijing, J. Environ. Sci., 54, 298-313, https://doi.org/10.1016/j.jes.2016.08.027, 2017.

Zheng, G. J., Duan, F. K., Su, H., Ma, Y. L., Cheng, Y., Zheng, B., Zhang, Q., Huang, T., Kimoto, T., Chang, D., Pöschl, U., Cheng, Y. F., and He, K. B.: Exploring the severe winter haze in Beijing: the impact of synoptic weather, regional transport and heterogeneous reactions, Atmos. Chem. Phys., 15, 2969-2983, https://doi.org/10.5194/acp-15-2969-2015, 2015. 